\title{
The Potential to Secure a Fair Trial Through Evidence Exclusion: A Chinese Perspective
}

\author{
Na Jiang
}

\begin{abstract}
This chapter addresses the People's Republic of China's aim to engage in comprehensive fact-finding before handing down punishments to wrongdoers. In 2012 exclusionary rules were added to the Chinese Criminal Procedure Law. In doing so, lawmakers restricted the pool of information accessible to the courts when deciding guilt or innocence of defendants. This change may also make it more difficult to establish the truth in criminal trials. On the other hand, the justification for excluding certain evidence was the discovery of ongoing torture occurring during criminal investigations, which eventually led to many miscarriages of justice. The initial legislation was initiated in 2010 by the Supreme People's Court. Efforts by the Supreme People's Procuratorate, together with three separate Ministries led to the modification of the Criminal Procedure Law. The exclusionary rules seek to make it more difficult to introduce illegally obtained evidence into a criminal trial, and particularly material acquired through torture. Nevertheless, the pressure upon judicial authorities to find perpetrators of crimes quickly remains. Thus, the drive to get confessions from suspects also continues.
\end{abstract}

\section{Introduction}

Many justice systems grabble with the conflict between determining what really happened when an alleged crime took place and ensuring that investigative methods do not violate the rights of the accused. This is true also for the Chinese justice system that in recent years has been accused of neither achieving either objective in social media. Especially cases in which violations of the rights of the accused lead to wrongful convictions have been exposed. The protection of human rights and the need to exclude improperly-obtained evidence is recognized by Chinese law. In practice, however, news reports suggest that suspects in Chinese criminal cases

\footnotetext{
N. Jiang $(\bowtie)$

College for Criminal Law Science, Beijing Normal University (BNU 北京师范大学),

Beijing, China

e-mail: na.jiang@bnu.edu.cn

(C) The Editor(s) (if applicable) and The Author(s) 2019

S. Gless and T. Richter (eds.), Do Exclusionary Rules Ensure a Fair Trial?

Ius Gentium: Comparative Perspectives on Law and Justice 74,

https://doi.org/10.1007/978-3-030-12520-2_6
} 
have been convicted based on false confessions, which have been extracted through torture. It is yet to determine whether these violations of human rights are the result of excessive zeal to obtain the truth, or caused by institutional structures that encourage authorities to obtain a conviction at all costs.

In a nutshell, Chinese law currently provides specific provisions for the exclusion of illegally-obtained evidence. In 2010, the Rules Concerning Questions about Exclusion of Illegally-Obtained Evidence in Handling Criminal Cases (Rules) were created by the Supreme People's Court (SPC), the Supreme People's Procuratorate (SPP), the Ministry of Public Security (MOPS), the Ministry of State Security (MOSS) and the Ministry of Justice (MOJ). The Rules were the first to set down ways in which illegally-obtained evidence should be excluded from use at criminal trials, but they regrettably failed to prevent wrongful convictions that were caused by the use of tainted evidence. In an attempt to succeed where the Rules failed, China's top legislature, the Standing Committee of National People's Congress, adopted a revised Criminal Procedural Law in 2012 (2012CPL), which became effective in 2013. The $2012 \mathrm{CPL}$ entrench the above exclusionary rules in formal law. Official reports claimed that the $2012 C P L$ would be a significant step towards the rule of law and the protection of human rights in China. ${ }^{1}$

Without anticipating the final findings of this report, but looking at discussion during the last decade, one may have doubts whether the legal rules have so far been effective. ${ }^{2}$ SPC Judges have admitted that 'almost all of recently identified wrongful convictions resulted from forced confessions', but 'judges still have many difficulties in excluding illegally-obtained evidence by law'. ${ }^{3}$ Judges fail to enforce laws because doing so is rational under the institutional arrangement in which judges are embedded. Currently, defence lawyers are placed in a very weak position, making it difficult for them to press for the exclusion of evidence. ${ }^{4}$ Also, judges are often 'unwilling, afraid or unable to exclude' evidence in practice. ${ }^{5}$ Even after People's Courts successfully exclude evidence extorted through torture in rare cases, the use of indirect evidence derived from extorted confessions is still permitted by law and in practice. Tolerating the "fruits of the poisonous tree" cannot make the exclusion of extorted confessions essentially influence final judgements or prevent wrongful convictions. In fact, People's Courts generally accept the prosecution's evidence material without cautious examination. Often, decisions rely on circular logic: judges do not examine case procedures, so cases must have been

\footnotetext{
${ }^{1}$ See Elaine Duan, 'Highlights of Criminal Procedure Law revision', China.org.cn, 12 March 2012, available online at <http://www.china.org.cn/china/NPC_CPPCC_2012/2012-03/12/ content_24876541.htm>, accessed 31 October 2018.

${ }^{2}$ See WU Hongyao, 2014 at 121-130; WANG Chao, 2013 at 100-108; DU Yusu, 2013 at 184189.

3 廉颖婷 (LIAN Yingting): 非法证据排除规则实施五年效果几何 (How is the Implementation Effect of the Exclusionary Rule for Five Years), Legal daily, 12 May 2015, available online at <http://law.southen.com/c/2015-05/12/content_124074146.htm>, accessed 31 October 2018.

${ }^{4}$ See NING Ping, 2015.

${ }^{5}$ ZUO Weimin, 2015b.
} 
conducted properly, which means judges do not need to examine them. Unless the traditional institutional constraints change, the use of tainted evidence to obtain convictions will continue. ${ }^{6}$ Thus, the transformation of China's criminal justice institutions is necessary to prevent the use of illegally-obtained evidence. One of the most important reforms that could be made would be to strengthen the ability of defence counsel to seek the exclusionary remedy.

\section{General Framework for Fact-Finding in Criminal Proceedings}

In Chinese legal framework for fact-finding, the major principle can be found in Art. 51 of the $2012 C P L$ as a general order to search for find the truth. In all criminal justice system, search for truth comes first, which is followed by individual rights later. The Constitution of the PRC (Constitution) and the 2012 CPL contain a series of explicit provisions pertaining to protecting individual rights, including those of suspects, the accused, witnesses and so on. Art. 37 of the Constitution generally prohibits unlawful detention of citizens or restriction of their personal liberty without mentioning fair trial or evidence exclusion. Art. 37 states that " $[\mathrm{F}]$ reedom of the person of citizens of the People's Republic of China is inviolable", " $[\mathrm{N}] \mathrm{o}$ citizen may be arrested except with the approval or by decision of a People's Procuratorate or by decision of a People's Court, and arrests must be made by a public security organ", and that "[U]nlawful detention or deprivation or restriction of citizens' freedom of the person by other means is prohibited, and unlawful search of the person of citizens is prohibited." Articles 39 and 40 also relate to prohibiting illegally obtained evidence. But other Chinese legislation specifically punishes the extortion of confession by torture or the use of force. The main provisions relating to the protection of rights include: Arts. 247, 248, 254 of the Criminal Law of the PRC (1997 CL), Arts. 14 and 22 of the Prison Law, Art. 22 of the People's Police Law, Art. 33 of the Procuratorate Law, and Art. 30 of the Judge's Law, of the PRC. Even so, the actual implementation of the provisions is still poor. Police investigators and even the public have a high tolerance for confessions extorted through torture, particularly for the purpose of maintaining public order or efficiently solving cases. ${ }^{7}$ Official assertions and data purporting to show a sharp decrease of cases involving torture have been challenged. ${ }^{8}$

\footnotetext{
${ }^{6}$ See Nolan, 2009 at 95.

${ }^{7}$ See KONG Yi, 2001; LIN Lihong/YU Tao/ZHANG Chao, 2006; DONG Xiaowei, 2004; LIN Lihong/YU Tao/ZHANG Chao, 2009.

${ }^{8}$ See 宋识径 (SONG Shijing): 刑讯逼供案件去年下降 87\% (The Cases of Inquisition by Torture decreased by $87 \%$ in the Last Year), The Beijing News, 27 June 2013, available online at <http:// epaper.bjnews.com.cn/html/2013-06/27/content_443457.htm?div=-1>, accessed 31 October 2018; CHEN Ruchao, 2015.
} 


\subsection{Legal Framework and Relevant Actors}

Concerning the duty to ascertain the truth, the 2012 CPL provides for the People's Court's duty to judge cases based on facts that 'are proved with evidence' 'beyond reasonable doubt' in Arts. 51, 53, 54 and 118. The duty is balanced with a series of rights enshrined mainly in Arts. 50 to 63 of the $2012 \mathrm{CPL}$. Among them, the right not to self-incriminate, the right to apply for the exclusion of illegally obtained evidence and the right not to be tortured or ill-treated are designed to protect suspects, the accused or witnesses from abuses of power during the criminal process.

Chinese courts include the Supreme People's Court, local People's Courts and special courts. The local People's Courts are divided into basic People's Courts, intermediate People's Courts and higher People's Courts, respectively at the level of counties, cities and provinces. Chinese courts independently exercise judicial power according to law, and shall not be subject to interference by any administrative organs, public organizations or individuals. That follows that Chinese People's Courts may not be independent from People's Procuratorates, or that People's Courts at lower levels depend on instructions from those at higher levels. Meanwhile, most of Chinese judges are appointed by leaders and the presidents or chief judges of Chinese courts are selected by people's congress. Even in law, there is no independence of judges, and courts' independence is limited, differing from judicial independence in the west.

Courts also have the duty to ensure the right to a fair trial. This duty is upheld by granting the accused the following specific rights: the right to equal treatment before the law, the right to a fair and public hearing, the right not to be found guilty except by a courts' judgement according to law, the right to criminal defence, the right to legal assistance, the right to be tried without undue delay, the right to be present during his or her trial, the right to cross-examine witnesses; the right to have the assistance of an interpreter; the right to appeal, the right to apply for compensation if wrongfully convicted or imprisoned.

Accordingly one could assume that the legislative preconceptions require courts to pay equal attention to both: a most comprehensive fact-finding, leading to the punishment of crime, and the safeguarding of individual rights of those affected by criminal investigation, especially the defendant. By law, courts must therefore strictly examine evidence and ensure that the fact-finding process does not violate the rights of any relevant party. Also, based on legal provisions, courts should exclude illegally obtained evidence from use in conviction to ensure justice based on facts and evidence, rather than cooperate with other justice agencies or follow leaders' instructions to wrongly convict the accused. In fact, courts often use the aim of crime control to justify any investigative method. ${ }^{9}$ Recommended reform will be outlined in conclusions or Chinese international human rights duties.

\footnotetext{
${ }^{9}$ More details will be further explained in 3.1.1.2, 3.2.3.2 and 3.3.2.2.
} 


\subsubsection{General Rules}

\subsubsection{Law Determining a Duty to Search for the Truth}

There are no constitutional rules that directly set out a search for the truth. However, some provisions in the $2012 C P L$ explicitly set out such a duty from diverse perspectives in several major aspects, as follows:

Firstly, some provisions set out the importance of searching for the truth. As Art. 51 of the 2012 CPL specifies, all "documents of a public security organ authorising arrest, all bills of prosecution of a People's Procuratorate and all judgments of a People's Court, must truly rest on facts." Accordingly, only facts and not confessions can become the basis of conviction or sentence in any court judgements. Also, Art. 51 explicitly imposes on the above three institutions the duties to prohibit "intentionally concealing facts" and to punish those doing so by law. If they do so against the accused, it could lead to self-incrimination in a broad sense.

Secondly, some provisions relate to the significance of confessions. As Art. 53 of the 2012 CPL provides, "emphasis must be placed on evidence, investigation and analysis, “... and [courts] shall not readily rely on confessions" when deciding cases. Accordingly, courts cannot by law reach verdicts based on confessions alone. Specifically, the law states that "the accused shall not be found guilty or imposed a criminal penalty" with only his/her confession, rather than other evidence", but, by law, "may be convicted or imposed a criminal penalty based on reliable and sufficient evidence" even "without his or her confessions at all".

Thirdly, some provisions prescribe the means by which the authorities can obtain confessions from suspects. Art. 54 of the 2012 CPL imposes on judges the duty to exclude the use of suspects' or the accused's confessions if they were obtained through torture, extortion or other illegal methods, apart from the obtained illegally witness testimony and victim statements. Also, Art. 54 requires the authorities to exclude physical or documentary evidence from use if it was collected contrary to legal procedures and could potentially seriously prejudice justice. However, such evidence can be included in the admissible scope if the evidence can be corrected or supplemented by investigators, or if a reasonable explanation be provided for its errors. Fourthly, some provisions dealt with how authorities may interrogate suspects. Art. 118 of the 2012 CPL requires investigators to begin interrogating suspects by asking "whether he or she has committed a crime or not, so as to let him/ her state details of the crime or explain his/her innocence", and "then ask other questions". In order to efficiently search for the truth, investigators are required to "inform criminal suspects of such legal provisions that they may receive lenient treatment after honest confessions" in Art. 118. This article is against the general principles of prohibiting extorted confessions in 1997 Criminal Law and in Art. 60 of the $2012 C P L$. This promise of leniency in Art. 118 may lead suspects to confess during interrogation or leave much room for investigators to misjudge or 
punish the silent innocent ${ }^{10}$ on the basis that they refuse to "truthfully" answer the questions that are put to them.

Additionally, there is no statutory or constitutional rule that formally recognizes acceptance of plea-bargaining in Chinese legislation. However, compulsory provisions on the imposition of lenient treatment in exchange for honest confessions may allow for a sort of plea-bargaining or indicate its implicit acceptance in practice. The cautious use of leniency in exchange for a confession is intended to promote efficiency and achieve justice.

\subsubsection{Law Securing a Fair Trial and/or Individual Rights}

\section{Constitutional Rules}

In China, the Constitution of the PRC (Constitution), adopted in 1982, is supreme over all other laws. It establishes essential national institutions, and sets out the basic rights and obligations of citizens, all of which embody primary policies or guidelines. In 2004, 'human rights' were newly enshrined as a principle in Art. 33 of the Amendment IV to the Constitution (2004 Constitution), without mentioning such basic rights as the right to a fair trial. The limited constitutional coverage of human rights appears to indicate the lack of importance that China attaches to the rights of the accused. Even so, there is no constitutional court at all in China. Also, the role that the 2004 Constitution plays in any court is often symbolic, because it is officially deemed as a national fundamental law, but cannot be used as substantive laws in application.

\section{Statutory Rules}

In order to implement human rights principle set down in the 2004 Constitution, the $2012 C P L$ both enshrines respect for and protection of human rights as its major task, and further improves the rights of suspects or the accused in the criminal process. Apart from the right not to self-incriminate oneself is introduced in Art. 50 of the $2012 C P L$ as new progress; other rights can be divided into three categories in light of their nature or function.

(a) The first category contains the right to defence and the right to legal aid.

Under Art. 125 of the 2004 Constitution that states that the accused has the right to defence, the $2012 C P L$ sets out the range of different aspects with which the defence system deals. The first aspect relates to the duty of justice authorities to inform criminal suspects of their rights. Art. 33 of the $2012 C P L$ provides for the investigation organ's duty to inform suspects of their right.

The second aspect is on the right to appoint or have defence counsel. The third aspect relates to the legal duties and rights of defense lawyers in the criminal

\footnotetext{
${ }^{10}$ See CHEN Ruihua, 2012 at 46.
} 
process. Their duties are "to provide materials and opinions proving suspects' or the accused's innocence or the limited seriousness of the crime, showing the mitigating circumstances of the case or grounds for exempting the accused from criminal liability, and protecting their procedural rights and other legal rights and interests" based on facts and the law. ${ }^{11}$ During investigations, defence counsel have the right to provide legal advice, the right to file petitions and accusations on behalf of their clients, the right to apply the modification of a compulsory measure, the right to learn details about the charges and case information from investigative authorities, and the right to offer opinions to judges. ${ }^{12}$ When examining the case of the prosecution, defence lawyers can consult, extract and duplicate materials, or meet and correspond with suspects in custody. ${ }^{13}$ Also, they can collect case materials from witnesses or others if permitted, and apply to People's Procuratorates or courts to request collection of evidence. ${ }^{14}$ As Art. 41(1) states, "[A] defense lawyer may gather information regarding a case from a witness or any other relevant entity or individual with the consent thereof, and may also apply to the People's Procuratorate or People's Court for gathering or submission of evidence or apply to the People's Court for notifying a witness to testify before court." Chinese counsels do need permission from witnesses or others. If the collection of evidence by counsel is forbidden by witnesses or other relevant institution or individuals, counsel have to ask for the relevant court's help to notify witnesses of testifying in court or to permit victims to offer counsels evidence.

A revision of the $2012 C P L$ grants a suspect access to legal counsel after the initial interrogation or upon the imposition of a coercive measure, so as to resolve inconsistencies. The changes stress the significant role that lawyers play in defending suspects during investigation, and augment the inequality of defense and prosecution (see Arts. 33-36 of the $2012 \mathrm{CPL}$ ). The reform furthermore provides lawyers with further guarantees 'to overcome difficulties in meeting suspects or defendants, accessing case material or obtaining evidence through investigation' ${ }^{15}$ Along with expanding the scope of legal aid to all stages of the process, the new changes also clarify lawyers' role in the final review of death sentences in order to enhance the rights guaranteed by Arts. 120, 222, 239 or 240 of the 2012 CPL.

However, the current law limits the right to defence in certain ways. Chinese law, i.e., Art. 40 of the $2012 C P L$, still does not fully meet the requirements of Art. 14(3)(b) and 3(e) of the International Covenant on Civil and Political Rights (ICCPR). One deficiency is that defence lawyers still face difficulties when collecting information from the victim, their relatives, and witnesses provided by the

\footnotetext{
${ }^{11}$ Art. 35 of the 2012 CPL.

${ }^{12}$ Art. 36 of the 2012 CPL.

${ }^{13}$ Arts. 37 and 38 of the 2012 CPL.

${ }^{14}$ Art. 41(1) of the 2012 CPL.

${ }^{15}$ Information Office of the State Council of the PRC, 'Judicial reform in China' (October 2012), available online at <http://www.chinadaily.com.cn/kindle/2012-10/10/content_15806147.htm>, accessed 31 October 2018.
} 
victim. The difficulty is created by the fact that both the consent and the permission of the People's Procuratorates or People's Courts are prerequisites to collecting information. But a lack of specific applicable conditions for granting permission leaves much room for the authorities to refuse applications for investigating evidence or asking witnesses to testify in court. The abuse of procuratorial power and judicial power hampers the ability of defence lawyers to collect evidence necessary for the defence of their client required to fully protect the right to defence.

Another limitation relates to obstacles defence lawyers face when trying to meet with some suspects. According to Art. 37 of the 2012 CPL, for instance, defence counsel who plan to meet 'a suspect of an offence that involves a crime endangering state security, a crime of terrorism or the particularly serious bribery crime' during investigation, 'should seek permission from the investigating authority'. As officially recognized in 2012, the bribery crime should involve the suspected amount of bribery no more than RMB 500,000, serious criminal circumstances, significant social impacts, or major national interests. The authority has the opportunity to refuse to allow such a meeting, and defence counsel have no remedy for such a refusal. The obstacle arises when defence counsel wish to meet with suspects under residential surveillance. It is hard for counsel to actually protect the above suspects, given the opportunity for the authorities to abuse their powers.

In the overall light of real politics, the worst limitation that defence lawyers face in practice is that the use of certain defence tactics may jeopardize their ability to practice law. Particularly combined with Art. 306 of the 1997 Criminal Law (CL), which is the current criminal law code of the PRC, the Art. 42 of the $2012 C P L$ obliges defence lawyers not to conceal, destroy or falsify evidence or modify witness testimonies. Article $306 C L$ is called as the 'Big Stick' hanging over lawyers' head in criminal defence, ${ }^{16}$ due to criminalizing defenders and agent ad litem who destroy evidence, falsify evidence, or interfere with witnesses' testifying. The authorities can use these provisions to punish defence counsel who present evidence that contradicts the prosecution's theory of the case. The threat of such a penalty often leads counsel to refrain from zealously upholding their clients' rights.

Moreover, the efficiency of exclusionary rules is highly influenced by inadequate defence. The $2012 C P L$ does not safeguard the right to prompt legal assistance following arrest or detention, but leaves the detained suspects subject to an initial interrogation without the presence of counsel or access to legal advice. Thus, counsel have no opportunity to collect direct evidence on the use of illegal means like torture to extort confessions from suspects or accused. The legal duty of suspects to tell the truth, combined with inadequate methods for excluding illegally-obtained evidence provides investigators with the ability and the motive for forcing suspects to confess. The law has not yet enshrined the right to silence or abolished the duty to provide investigators with the facts, not to mention guaranteeing the presumption of innocence. Given these shortfalls, most accused are still likely to be presumed to be guilty in reality, in spite of the aforementioned reforms.

\footnotetext{
${ }^{16}$ YU Ping, 2002 at 857.
} 
(b) The second category of legal rights are those that allow suspects to request that justice bodies examine, change or withdraw disadvantageous conduct, decisions or judgements made by others. As well as the right to appeal or present a petition against conviction or sentencing, the convicted enjoy the legal 'right to file charges against judges, prosecutors and investigators' for violating their procedural rights or subjecting them to indignities. ${ }^{17}$

Defendants or their legal representatives 'have the right to appeal [first-instance judgements] in writing or orally' to the court 'at the next higher level'. ${ }^{18}$ Defence counsel and relatives of the defendant may only file an appeal 'with the consent of the defendant'. ${ }^{19}$ Appeals resolve around the convictions or sentences of defendants, which is designed to protect their right to appeal from being violated in the criminal process.

It is worthy of note that, in principle, no appeal from a defendant can result in additional criminal punishments. The use of the principle against stricter punishment following an appeal from the defence is designed to encourage defendants to appeal without having to worry about increased punishment, so as to better protect their rights and achieve greater justice. However, the prosecution is also able to appeal and request a stricter sentence, and sometimes both parties' appeals are heard concurrently.

(c) The last, but not the least, group of rights includes procedural rights that arise from the legitimate duties of judges, prosecutors and investigators. Such rights mainly involve the right of suspects or the accused to equality before the law, ${ }^{20}$ their right not to be convicted without a court verdict according to the law, ${ }^{21}$ their right to a public and independent trial, ${ }^{22}$ the right of ne bis in idem $^{23}$ and of nulla poena sine lege. ${ }^{24}$

\section{International Human Rights Law}

China is bound by international laws that affect how its trials are conducted, but has not yet ratified the ICCPR after signing it in 1998 and actually deviates from international standards to a large degree. Primary international human rights instruments contain the right to a fair trial, though they do not provide a definition of what exactly that means. The right might be customarily subsumed in 'judicial guarantees'. A series of human rights standards pertaining to the right to a fair trial,

\footnotetext{
${ }^{17}$ Art. 14 of the 2012 CPL.

${ }^{18}$ Art. 216(1) of the 2012 CPL.

${ }^{19} \mathrm{Ibid}$.

${ }^{20}$ Art. 6 of the $2012 C P L$.

${ }^{21}$ Art. 12 of the 2012 CPL.

${ }^{22}$ Art. 5 of the 2012 CPL.

${ }^{23}$ Art. 10 of the 2012 CPL.

${ }^{24}$ Art. 12 of the 2012 CPL.
} 
i.e., Arts. 6(2), 14(1) of the ICCPR, Arts. 2(1), 6 of the ECHR and Arts. 4(2), 8 of the $A C H R$, require State parties to observe related standards. Major resolutions of the United Nations Economic and Social Council also deal with a fair trial. These resolutions act as "soft laws" that urge all States to respect the right to a fair trial. ${ }^{25}$ The "fair trial" mandated in Art. 14 of the ICCPR is further incorporated into Art. 6 of that instrument, which cannot be suspended in emergency, which makes the right non-derogable in all criminal cases. ${ }^{26}$ Fair trial appears in the $2012 \mathrm{CPL}$ only and not in practice. Among minimum guarantees of fair trial, the 2012 CPL partly protects the rights to be informed of charges, to be tried without undue delay, to defence, to call and examine witnesses, and to appeal, but never mentions the presumption of innocence. In practice, no minimum guarantee can be ensured totally.

Moreover, Art. 14(1) of the ICCPR indicates that 'a competent, independent and impartial' trial by law on the basis of equality 'before the courts and tribunals' is the requirement for a fair trial. Arts. 14(2)-(7) of the ICCPR require States to offer all accused persons the minimum rights guarantees established by law that define and guarantee rights at trial. General Comment No. 06 also stresses that 'procedural guarantees therein prescribed must be observed, including the right to a fair hearing by an independent tribunal, the presumption of innocence, the minimum guarantees for the defense, and the right to review by a higher tribunal. ${ }^{27}$ These procedural guarantees contribute to a fair trial and apply universally to all trials.

The right to 'be equal before the courts and tribunals' contained in Art. 14(1) of the ICCPR clarifies the general principle of equality in Art. 26 of the ICCPR. The right to a fair and public hearing pursuant to Art. 14(1) of the ICCPR is the core of due process. All provisions in Art. 14(2) to (7) and Art. 15 of the ICCPR specify this right. Aside from institutional guarantees, Art. 14(1) of the ICCPR requires the establishment of a competent, independent and impartial tribunal by law to determine criminal charges in a fair and public hearing and to pronounce them publicly.

The ICCPR provides minimum guarantees to the accused, including the presumption of innocence, the right to be informed of charges, the right to be tried without undue delay, the right to defence, the right to call and examine witnesses, and the right to appeal. Art. 14(2) of the ICCPR provides the right to be presumed innocent for everyone who is charged with criminal offences 'until proved guilty according to law'. Judges have the duty not to convict an accused unless on the

\footnotetext{
${ }^{25}$ Economic and Social Council, 'Safeguards Guaranteeing Protection of the Rights of Those Facing the Death Penalty. 45th plenary meeting (23 July 1996)' E/RES/1996/15 (1996), available online at <http://www.un.org/documents/ecosoc/res/1996/eres1996-15.htm>, accessed 31 October 2018.

${ }^{26}$ United Nations Human Rights Committee, 'CCPR General Comment No. 6 Art. 6 (Right to Life). Sixteenth Session (30 April 1982)' (1982), available online at <http://www.refworld.org/ docid/45388400a.html>, 31 October 2018.

${ }^{27}$ See footnote 28 .
} 
basis of reasonable grounds of guilt, in order to 'refrain from prejudging the outcome of a trial', as stressed by the Human Rights Committee. ${ }^{28}$ Art. 14(3)(a) of the $I C C P R$ contains the right of an accused to 'be informed promptly and in detail in a language which he understands of the nature and cause of the charge against him', thus imposing obligations on the State. The duty to inform requires that information must be sufficient to allow him or her to prepare for a defence, as per Art. 14(3)(b) of the ICCPR. In criminal hearings, the authority has the duty to supply translation services under Art. 14(3)(f) of the ICCPR.

Art. 14(3) (c) of the ICCPR stipulates that any person charged with a criminal offence has the right ' $[\mathrm{T}] \mathrm{o}$ be tried without undue delay', implicit in Art. 9(2) and (3) of the ICCPR. This claim relates to the pronouncement of definitive judgements $^{29}$ and overlaps with the guarantee in Art. 9(3) of the ICCPR on the pre-trial detention. Art. 14(3)(d) of the ICCPR specifies the right to a defence as comprising five categories of individual rights. They are: the right to be tried in one's presence; the right to defend oneself in person; the right to choose one's own counsel; the right to be informed of the right to counsel; and the right to receive free legal assistance. Such legal representation must be available at all stages of criminal proceedings. Art. 14(3)(b) of the ICCPR involves the right of accused persons to 'have adequate time and facilities for the preparation of his defence'. What constitutes "adequate time" generally depends on the circumstances and complexity of particular cases. The word 'facilities' grant the accused or his defence counsel the right to access the documents necessary for trial preparation. Art. 14(3)(b) also contains the accused's right 'to communicate with counsel of his own choosing'. This right is solely directed to the preparation of the defence, especially when the accused is held in pre-trial detention.

Under Art. 14(3)(e) of the ICCPR, the right to 'obtain the attendance and examination of witnesses' 'under the same conditions' as the prosecutor is an essential element of a fair trial. It guarantees that the accused parties are treated equally on the interrogation of witnesses and the introduction of evidence. The right of the accused to 'obtain the attendance' is restricted 'under the same conditions as witnesses against him'. Art. 14(5) of the ICCPR safeguards that everyone 'convicted of a crime shall have the right to his conviction and sentence being reviewed by a higher tribunal according to law'. This general formulation recognises the right of convicts to appeal.

\footnotetext{
${ }^{28}$ United Nations Human Rights Committee, 'CCPR General Comment No. 13: Art. 14 (Administration of Justice), Equality before the Courts and the Right to a Fair and Public Hearing by an Independent Court Established by Law. Twenty-first Session (13 April 1984)' (1984), available online at <http://www.refworld.org/docid/453883f90.html>, accessed 31 October 2018.

${ }^{29} \mathrm{Ibid}$.
} 


\subsubsection{Law Balancing a Duty to Determine the Truth and Infringements on Individual Rights}

Concerning the balance between a duty to tell the truth and infringements on the right not to self-incriminate themselves, the $2012 C P L$ imposes the duty on all suspects to "answer the questions of the investigatory personnel truthfully" in Art. 118 , but it also provides suspects with the right not to "be forced to prove his or her own guilt" in Art. 50. The importance of confession is highly stressed, so the right to silence has not yet been established in China. There is a great need for the introduction of legislation to protect the right to silence.

Art. 118 of the $2012 C P L$ implies that suspects have no right to remain silent when being questioned. The provision is especially important to investigators, given their dependence on confessions in clearing up criminal cases. But from the perspective of the better protection of the rights of suspects or accused under the principle of human rights, one possible interpretation of Art. 118 is that the law allows them remain silent, but requires them to tell the truth if they waive that right. ${ }^{30}$ In other words, there might be the right to silence, but no right to lie. The institutions of the Chinese justice system do not yet recognize the right to silence as "possible interpretation" that Art. 118 set out above and this deficiency needs to be rectified. In the systemic context of the law, it is necessary to adopt an interpretation that preserves the right to silence.

Meanwhile, it is worthy of note that no article in the 2012 CPL explicitly articulates criminal suspects' right to silence, including Art. 50, which comes closest to doing so. Therefore, many legal scholars in China do not consider this right to be fully established. Even if Chinese law has already established an implied right to silence, there is still a long way to go before the ideal system is transformed into a real one. First, the legislature and judiciary should clarify the right of suspects and the accused to remain silent under interrogation when they implement the interpretative regulations of the $2012 C P L$. Second, the judiciary should further improve the exclusionary rules on illegal evidence and specify the circumstances in which evidence obtained illegally should be excluded. Furthermore, investigators should be fully recorded when interrogating suspects to protect the human rights of the accused, who are innocent until proven otherwise. Prosecutors should also adhere to the principle of handling cases by law. In a nutshell, it is necessary to make the Chinese right to silence worthy of the name.

In order to balance a duty to determine the truth and infringements on individual rights, the $2012 C P L$ requires the authorities not to seek the truth at any costs, but to protect from abuse the human rights of suspects, the accused and witnesses. Particularly, they should exclude illegally obtained evidence from use, and should also not force anyone to confess or testify by torture or undue coercion.

\footnotetext{
${ }^{30}$ See 何家弘 (HE Jiahong): 从新刑诉法看中国已确立沉默权制度 (In View of the New Criminal Procedure Law China Establishes the Right to Remain Silent), Renmin Fayuan Bao, 1 August 2012, available online at <http://www.chinacourt.org/article/detail/2012/08/id/538703. shtml>, accessed 31 October 2018.
} 
Accordingly, the right of suspects not to self-incriminate themselves, the right of suspects or witnesses not to be tortured or ill-treated, and the right to apply for excluding illegally-obtained evidence should be fully protected throughout the criminal process.

Specifically, the law is concerned with the significance of confessions or other statements, as well as the legality of collecting and using such statements as evidence. As provided in Art. 50 of the 2012 CPL, confessions in any form can be used for conviction or acquittal if the authorities collect them according to legal procedures. For protecting the right not to self-incriminate and the right not to be forced to prove one's innocence, it is strictly prohibited to extort confessions by unlawful means, including threats, inducement or deceit. When torture or undue coercion are employed, coerced confessions, witness testimony and victim statements should be excluded from use, as required by Art. 54 of the 2012 CPL.

However, there is no explicit provision in the $2012 C P L$ on a standard procedure to test whether or not torture was applied to a suspect. The procedure for excluding illegally obtained evidence may involve examination of evidence extorted through torture to a certain degree, which can be addressed in detail as follows:

There are two main approaches for initiating the procedure for testing whether torture has occurred, which are based on the legal procedure for excluding evidence. One approach is initiated by judges. After noticing the potential that torture was used in the course of evidence collection, they should take the initiative to exercise their legal power during court hearings to investigate the manner in which evidence was collected. The other approach is based on an application by a party in the trial to the relevant court. As provided in Art. 56 of the 2012 CPL, the parties, defence counsel or representatives of the accused have the legal right to apply to the People's Court for the exclusion of evidence obtained by illegal means like torture. The first and foremost issue that courts should examine when deciding whether to exclude evidence is whether torture was used to collect it.

Furthermore, potential difficulties in taking the second approach are implied in Arts. 56-57 of the 2012 CPL, and Arts. 97, 101 of its Interpretation as well. At first, applicants should provide a court with information and materials on the persons involved with the alleged torture, the time and place when it allegedly occurred, and the means by which it was allegedly conducted in their application for excluding illegally-obtained evidence. Next, it is at the discretion of the court to decide whether to investigate torture in a hearing. If the court initiates a hearing, prosecutors should present evidence to prove the legality of evidence or the fact that torture was not used, i.e., by playing a video or audio recording. Given courts' great discretion when investigating torture, as well as all justice officers' tolerance of torture, the procedure does not actually provide much assistance in revealing whether or not torture was actually used. 


\subsubsection{Fact-Finding Procedure-Stages and Rules}

In China's criminal justice system, there are several primary stages, with diverse rules applying at each stage. This is particularly the case for the legal structure governing procedures for fact-finding.

Specifically, the ordinary fact-finding procedures that are universally applicable to all cases basically involve each stage of the criminal process. During investigation, the police 31 "conduct preliminary interrogation and verify the evidentiary materials" "where there is evidence of the existence of facts of a crime", as per the 2012 CPL. During interrogation, investigators must inform suspects of legal provisions regarding "lenient treatment for their honest confessions". Investigators must also make an "entire and complete record" of the interrogations of suspects facing life imprisonment or the death penalty. When questioning a witness, investigators are also required by law to inform him or her "that evidence or testimony provided by him or her shall be based on facts".

For initiation of public prosecutions, the People's Procuratorate should ascertain whether or not the criminal facts or details are clear, whether evidence is reliable or sufficient, whether the nature or charge of crime is correctly determined, and whether the investigative acts used to gather evidence were legal. In examining case facts, the People's Procuratorate by law should also interrogate suspects and listen to the opinions of both, the accused and the People's Procuratorate. If the People's Procuratorate believes the fact to be clear and the evidence to be reliable and sufficient, a decision should be made to initiate a prosecution.

Where the prosecution can clearly set out facts underlying a given criminal charge, the court must hold an open hearing. After a prosecutor has read out particulars of the charge at trial, the accused and victims may state the alleged crime, and then the procurator may interrogate the accused. If witnesses should testify in court but fail to do so, the court may compel them to testify. By law, only after the facts and evidence are debated and witnesses have been examined can the court decide a case law. If case facts are clear and evidence is reliable and sufficient, the court should convict the accused and impose an appropriate sentence. Otherwise, the accused should be acquitted.

Apart from aforementioned three basic steps to a criminal trial, fact-finding procedures applying to special cases may involve four more stages, namely, appeal, death penalty review, trial supervision and execution. Either the defendant's appeal or the People's Procuratorate's protest can initiate the appeal procedure. Appeal courts should completely review the facts found and the law applied in the original judgements in order to correct errors in convictions or sentences. After a complete

\footnotetext{
${ }^{31}$ In this context, police mean investigatary organs, mainly including public security authoritiesand national security authorities.The formeris responsible for criminal investigation, detention, execution of arrest warrants, and interrogation in criminal cases, and the later handles criminal cases regarding compromising national security and performs the same functions as those of public security authorities by law.
} 
revision, the courts may affirm an initial decision, revise judgements, or return cases for retrial by a new collegial panel.

Chinese law mandates that death sentences should be reviewed by the Supreme People's Court (SPC). During the review of death sentences, the SPC should interrogate the person on whom the sentence has been imposed and should hear arguments from his or her defence lawyers' opinion upon the lawyers' request. The SPP may advise the judges of the SPC of its opinions on the sentences and the SPC should, in turn inform the SPP of its final decision, apart from informing the accused whose sentence is being reviewed.

The court should open a new trial if the party's petition satisfies one of the following conditions: Firstly, if the petition introduces new evidence that proves that the determination of facts in the original judgments or orders was clearly wrong, and that it is likely to affect conviction and sentencing. Secondly, if the petition shows that evidence used when deciding the case or during sentencing is unreliable or insufficient, should have been excluded by law, or that major evidence regarding case facts is conflicting. Thirdly, if the petition can demonstrate that the judges applied the wrong law. Fourthly, if the petition can demonstrate that violations of legal procedures during the initial trial may have impaired its fairness. Fifthly, if it can be demonstrated that the trial judge was engaged in embezzlement, or the acceptance of bribes, the practice of nepotism, or that he or she was influenced to "bend" the laws when making his or her judgement.

In addition, fact-finding procedure is also found in enforcing criminal penalties. By legislation, those instructing execution or enforcement should verify the identity of criminals.

Differing from the above requirements in legislation, death penalty reviews are conducted without transparency, so the SPC actually dominates the review process. Generally the person whose sentence is being reviewed must passively wait for the SPC's decision. In practice, the ability of defence counsel to effectively participate in the process or to bring new facts to the attention of the SPC limits the ability of the procedure to correct errors. The death penalty review procedure does not meet the requirements set down by the minimum guarantees of due process.

\subsubsection{Fact-Finding Procedure-Actors and Accountability}

As important actors in the fact-finding procedure, People's Courts, People's Procuratorates and the police (the "three justice authorities") ${ }^{32}$ should use facts as the basis of handling a criminal case. Parties to the case, mainly including victims, private prosecutors, suspects and the accused, also play an essential role in seeking the truth, albeit they do so when trying to protect their own rights and interests.

\footnotetext{
${ }^{32}$ People's Courts are "ren min fayuan" in Chinese pinyin, People's Procuratorates are "ren min jiancha yuan" and the police are "gong anji guan" in general. The three of them are called "san ji guan" in Chinese pinyin.
} 
Other actors, i.e., legal representatives, agents ad litem, defenders, witnesses, experts or interpreters, assist their clients or the authorities to efficiently ascertain the facts.

Among these actors, both the People's Procuratorates, as the public prosecution organs, and private prosecutors are placed in the position of the accusing party, respectively in the cases of public and private prosecutions. Both public and private prosecutors not only should collect or present evidence to prove the facts of the case or their claims favourable to prosecution in court, but also should bear the burden of proof by law, so as to face adverse consequences for their failure to proving facts or claims. In this point, the police and courts differ from the People's Procuratorates because they do not bear the responsibility for proving facts at trial.

The three justice authorities have diverse legal powers and duties relating to fact-finding. Among them, the police mainly exercise investigative powers to find facts or collect evidence in order to assist People's Procuratorates to prepare for prosecution. The People's Procuratorates must further examine the facts and evidence provided by the police before presenting them to courts. After hearings, the courts should independently and impartially judge which party's claims are well-established. Apart from fulfilling their own responsibilities, the three should coordinate and check with each other to correctly and promptly determine the facts of guilt or innocence by law.

Unlike the prosecution, the accused or suspects should in principle not bear the burden of proving the facts or demonstrating their own guilt or innocence. Together with the accused's legal duty to truthfully answer questions, a lack of the right to silence suggests that they might be forced to confess during interrogation. Also, there are a few exceptions to the above principle in law. For instance, suspects and the accused are legally required to include relevant information or materials relating to illegally obtained evidence in applications to exclude such evidence from use.

As non-parties, representatives, agents ad litem, witnesses, expert witnesses or interpreters have no direct interest in the outcome of the cases with which they are involved, but they still play an essential role in fact-finding. For example, legal representatives can directly represent the relevant party, helping him or her exercise rights or complete his or her duties perform duties. Even without the right to state case facts or testify in court on behalf of the party, legal representatives can request the People's Procuratorate to lodge a protest against judgments due to errors in the facts of a case. Their general rights or powers are based on legal safeguards, rather than judicial decisions or approval, in order to effectively help the party with no or a limited capacity to actually attend proceedings.

Once entrusted, agents ad litem can protect their clients' rights and interests by participating in fact-finding within a commission scope on behalf of victims. Defenders and agents ad litem who help to conceal, destroy or falsify evidence, who threaten or induce witnesses to alter testimony, or who perjure or had commit other acts to interfere with judicial activities, are held legally accountable for their offences. 
Witnesses who have knowledge of case details have the duty to provide evidence or testimony based on the truth. ${ }^{33}$ Those who intentionally give false testimony or conceal evidence of guilt are legally accountable. Assigned or hired experts and translators are involved in fact-finding. Expert witnesses can use expertise or skills to give written examination advice on special problems in order to assist judges to find the facts. Those who deliberately provide false examination results are legally accountable. Additionally, translators should faithfully provide clients with translation services.

\subsection{Social Relevance of the Truth and Individual Rights in Criminal Trials}

\subsubsection{Relevance of Determining the Truth}

The relevance of determining the truth is highly stressed in the Chinese criminal justice system. The $2012 C P L$ suggests the significance of obtaining a confession from suspects or the accused. For example, Art. 118(2) of the 2012 CPL explicitly requires the accused or other suspects to answer the relevant "investigators' questions truthfully" during interrogations. Certainly in this context, the questions that suspects have to truthfully answer indeed include those on case facts, e.g., whether or not he or she committed crime. Thus, the clause fails to constitute the prohibition of self-incrimination, not to mention protecting his or her right to silence.

The diverse possible interpretations of the 2012 CPL regarding the right to silence leave much room for the authorities to abuse their powers. If suspects rely on Arts. 50(2) and 118(2) of the 2012 CPL to make full use of their right to refuse to answer questions irrelevant to the case, investigators could resort to Art. 118(2) to ask them to perform their duty to truthfully answer questions. Also, it is not difficult for investigators to find some relevance of their questions to the case, i.e. they might need an oral confession to assist with further investigations. Under this interpretation, investigators can justify the potential relevance of their questions by any means, suspects lose their right to silence and have to confess their guilt. If this interpretation prevails, the legal principle of prohibiting self-criminalization in Art. 50 (2) of the $2012 C P L$ would likely become a rule on paper, rather than in practice.

Like any employees trying to meet managerial targets, some investigators often take advantage of loopholes. In the criminal justice context, such loopholes include the extortion of false confessions by means fair or foul, including torture. In order to reach the rigid target for solving cases, the authorities may resort to falsifying guilt,

\footnotetext{
${ }^{33}$ Art. 123 of the 2012 CPL states that "[W]hen a witness is interviewed, the witness shall be informed of the requirement of truthfully providing evidence and testimony and the legal liability for perjury or concealing criminal evidence.
} 
possibly by extracting a false confession from the first suspect to be arrested. As long as such a confession is obtained, a case is considered to be solved for the purpose of meeting the target. For example, Shanghai and Beijing, where nearly 99 and $99.16 \%$ of cases were solved in 2013 , achieved the highest rates of solved homicide cases in China. ${ }^{34}$ The managerial system can cause injustices. Identified wrongful convictions also demonstrate a high risk that tortured confessions will first be used at trial.

On the other hand, the $2012 C P L$ improves evidentiary rules to further emphasize the significance of making confessions public during trial. Art. 121 of the law requires investigators to make a complete audio or visual record of the entire interrogation process in cases in which suspected criminals may be punished by life imprisonment or the death penalty. In theory, if recordings are played back and made public, that would make cases of tortured confessions easy to identify, but recordings are often not complete with lawyer's absence in the course of interrogation. Given the legal incentive of leniency when punishing those who confess and the widespread use of torture, almost all suspects confess under the pressure of torture. Combined with a possibility of playing the record to examine confessions at trial as required by Art. 80 of the Interpretation on the $2012 \mathrm{CPL}$, transparency of investigation can be increased to make them public, thus reducing confession reached through torture.

In court hearings, confessions regarding case facts or evidence should be investigated and debated, so that judges can examine whether it is true or false and decide whether or not to use it as evidence. False confessions cannot be used to support a conviction. Also, judges should examine whether the collection of a confession was contrary to law. By Art. 54 of the 2012 CPL, confessions extorted by torture should be excluded from use. According to the Interpretation of the law, Art. 81 also prohibits the use of confession without confirmation in transcripts, or from the deaf, dumb or those unfamiliar with local languages, unless they were provided with assistance regarding translation. Accordingly, at trial making the record of confessions public can help courts examine all material evidence to exclude false or coerced confession in facts-finding. In order to promote publicity help this, there is a great need for judges to abandon privately reviewing evidence of torture in practice.

The Decision, made by the third Plenary Session of meeting of the Communist Party of China (CPC) in 2013, also requires that strict prohibitions be placed on extorting confessions by torture, particularly through applying exclusionary rules to

\footnotetext{
${ }^{34}$ For example, see 北京警方年度工作报告出炉命案破案率达 99.16\% (The Beijing Police Annual Report Was Released to Show that the Detection Rate of Murder Cases Rose up to 99.16\%), Zhongguo Net, 24 January 2014, available online at <http://www.china.com.cn/news/ 2014-01/24/content_31289621.htm>, accessed 31 October 2018; also see 潘高峰 (PAN Gaofeng): 去年上海命案破案率近百分之九十九 (The Shanghai Detection Rate of Murder Cases Being Nearly $99 \%$ in the Last Year), Dayang Net, 12 January 2014, available online at <http://roll.sohu. com/20140112/n393370187.shtml>, accessed 31 October 2018.
} 
illegally obtained evidence. Under political guidance, the SPC released the Directive to stress the implementation of exclusionary rules and the trial-centered doctrine in 2013. Following the acquittal of NIANB in, who was convicted of murder four times in the past ten years and was finally exonerated of all crime in 2014, Procurator-General CAO Jianming urged prosecutors to break away from their excessive reliance on confessions. ${ }^{35}$ The discovery of NIAN's innocence raised public outcry for the proper implementation of laws, which in part contributed to CAO's pledge.

However, legislation does not clarify lawyers' role in interrogation so that they have no legal way to protect their clients' rights from power abuses. In the NIAN Bin case, for instance, lawyers could not obtain a copy of the recording until it was played back at trial. Even then, their applications for excluding illegally obtained evidence were repeatedly rejected by courts. Worse than that, prosecutorial supervision over interrogations and investigations has actually tolerated tortured confessions in practice. Given the lack of an effective remedy for rights breaches and the closed environment of interrogation, police investigators often select a part of interrogation for recording favourable to the interests of the investigation. Thus, the recording system becomes a legal cover for illegal interrogation.

\subsubsection{Presentation of "Fact-Finding" and/or "Truth" to the Public}

\subsubsection{Publicity of Fact-Finding Before a Judgment}

Publicity of fact-finding including confessions before judgments may help the public better understand case facts and also urge judges to cautiously exercise judicial power. As Art. 11 of the 2012 CPL requires, courts shall hear cases in open trial, except as otherwise provided by this Law. Accordingly, open trial is courts' legal duty, during which confessions will be publicized for public supervision over the judiciary.

In practice, courts selectively allow substantive trial information, i.e., confessions or facts in doubt, to be open to the public. In hearing high-profile cases, courts should arrange a suitable place for the trial according to the number of the parties' close relatives, media reporters and the public in audience, but often set obstacles to their attendance by providing a small place. Courts also should give priority to the media's and their relatives' needs, but actually limit some media's attendance and publicity.

\footnotetext{
${ }^{35}$ Mark Godsey, 'China's Top Prosecutor Vows to Fight to Prevent Wrongful Convictions', ShanghaiDaily.com, 8 September 2014, available online at <https://wrongfulconvictionsblog.org/ 2014/09/08/chinas-top-prosecutor-vows-to-fight-to-prevent-wrongful-convictions/>, accessed 31 October 2018.
} 


\subsubsection{Existence of Court TV}

Some of court trials can be broadcasted live, as a permissible way to publicize confessions in fact-finding. The SPC's Six Provisions on Judicial Transparency issued in 2009 requires courts to meet the needs of the public and the media in understanding live trials by the means of court trial video, live video or others. The SPC's 2013 Pilot Programs on Promoting Three Platforms for Judicial Transparency requires courts to make public the hearing process in the ways of video, audio, graphics and micro-blog.

Through broadcast live, details on cross-examination and debates at trial are open to the public so that they can understand controversies between two sides in order to supervise and evaluate court trial. Thus, everyone can fully know and judge whether there is illegal means for collecting evidence in interrogations, and whether courts should exclude such evidence from use. For example, how the prosecution answer questions on the documented evidence that suggests defendants' tortured confessions, and how courts examine it for decision-making will be live through micro-blog. Once the public knows flaws in evidence, it will be hard for any court to tolerate them. ${ }^{36}$

Moreover, broadcast or webcast live only makes trial and not decision-making public, both of which are separate from each other in reality. Whether to publicize the truth also depends on superiors' or leaders' willingness. Courts mainly focus on assessments on their work achievements, rather than enhance judicial transparency. 37

\subsubsection{Public Discussion of Miscarriages of Justice}

In social media or print media, the public share the opinion that factual, legal or procedural errors in fact-finding may constitute or lead to more miscarriages of justice. A number of wrongful convictions were caused by coerced and false confessions obtained through torture against law and justice. It is generally accepted by the public, officials and scholars at home and abroad that illegally obtained evidence is the main cause of almost all known wrongful convictions in China. ${ }^{38}$ Some of official commentators or top leaders have admitted that illegal methods have been used to gather, examine and exclude evidence in various cases in recent decades.

In fact, the term 'miscarriage of justice', (a translation of cuòàn, lit. 'wrong cases'), is short of a universal definition, as is indicated in the relevant judicial interpretation issued by the SPP, local (non-national) regulation enacted by the local People's Congress and various instruments adopted by police and judicial organs at

\footnotetext{
${ }^{36}$ ZHOU Changjun, 2014.

${ }^{37}$ XIE Peng, 2012 at $65-75$.

${ }^{38}$ HE Jiahong, 2012.
} 
the basic level. The concept has been broadly applied by Chinese courts to any criminal proceeding 'where there was human error in the basic facts, underlying evidence or applicable laws, caused by police, procuratorates, courts [and/or state security organs]'. ${ }^{39,40}$ These bodies do not limit miscarriages of justice to cases of proven or factual innocence, but include those with procedural errors as well as unfair or partial trials which render criminal convictions factually unreliable even without fresh evidence. Thus, such convictions in China can be both re-opened and quashed on the grounds of proven innocence, or of substantive or procedural unfairness. Proper fact-finding can ensure justice at trial.

Despite the inertia and corruption of Chinese criminal justice system, the scope of what constitutes a miscarriage of justice should further expand in order to properly and effectively prevent wrongful convictions, as a part of ongoing reforms to China's judicial system. It is worthy to note that a system of accountability for miscarriages of justice, which is one of the SPC's judicial reform tasks, is intended to strengthen supervision over and decrease the number of illegal trials or other miscarriages of justice in criminal cases, albeit excluding the differences in legal recognition among judges, as revealed by the senior ones from the SPC. ${ }^{41}$

Furthermore, the issue of what constitutes wrongful convictions in China remains to be clarified. While any level of courts can declare that a miscarriage of justice has occurred, sometimes expressly describing particular cases in such terms, there are profound lessons to learn from high profile or long standing convictions that have been overturned on the basis of fresh evidence. ${ }^{42}$ In practice, the official media generally support the opinions of politicians or senior judges so as to shield them from criticism. More attention is paid to the vulnerability of current justice systems, whereas not all of those wrongfully convicted in the view of media would be necessarily acquitted or fully exonerated by courts, e.g., certain controversial illegal money-raising case. ${ }^{43}$ Increasingly in contemporary society, the recognition of innocence and exoneration has been sharply defined and universally acknowledged to be 'a political, social and scientific process that is not fully supported by the criminal justice system'. ${ }^{44}$ Neither the wrongly convicted SHE Xianglin nor

\footnotetext{
${ }^{39}$ ZHANG Jun, 1990 at 3.

${ }^{40}$ In China, the People's Procuratorates (PPs) are agencies that combine the functions of prosecutors, investigators, court supervisors and penal officials.

${ }^{41}$ 孙莹 (SUN Ying): 最高法: 132 项司法体制改革任务完成 103 项 (The SPC: 103 judicial Reform tasks have been finished in the total of 132), Renmin Net, 20 March 2012, available online at <http://legal.people.com.cn/GB/188502/17441465.html>, accessed 31 October 2018.

${ }^{42} \mathrm{See}$ 命案必破, 疯人顶罪? (Homicide must be detected, the insane being scapegoats?), Nanfang Net, 6 May2010, available online at <http://view.news.qq.com/a/20100511/000014.htm>, accessed 31 October 2018; See also 'Judicial reform in Henan gets public support (2)', People's Daily Online, 12 December 2011, available online at <http://english.peopledaily.com.cn/102774/ 7674038.html>, accessed 31 October 2018.

${ }^{43} \mathrm{See}$ 'Wu Ying case underlines need for private financing reform', Xinhua Net, 21 April 2012, available online at <http://news.xinhuanet.com/english/china/2012-04/21/c_131541731.htm>, accessed 31 October 2018.

${ }^{44}$ See Roach, 2009; Sherrin, 2010.
} 
ZHAO Zuohai's factual innocence could be officially recognized until judicial exonerations, followed with their DNA testing and other legal procedures, even if there was a remarkable consensus on serious doubts retained before convicting them. ${ }^{45}$

\section{Limitations of Fact-Finding in Criminal Proceedings}

\subsection{General Rules of Evidence Taking (Admissibility of Evidence)}

\subsubsection{Legal Framework}

\subsubsection{Legal Framework for Evidence Taking/Admissibility of Evidence}

\section{Legal Framework and Its Context on the Books}

Within the legal framework for evidence taking in China, the relevant evidence rules in the Criminal Procedure Law of the PRC, the Constitution of the PRC, the Convention against Torture, and judicial interpretations contribute to regulating the use of evidence. In the Constitution of the PRC, Art. 37 provides that Chinese citizens' personal freedom is inviolable. Also, Art. 39 requires that their home is inviolable, and Art. 40 provides that their freedom and privacy are protected by law.

Among the above framework, the 2012 Criminal Procedure Law of the PRC is a main source of evidence rules in the criminal process.

Concerning judicial interpretations, the Supreme People's Court's Interpretation on Several Issues regarding Enforcement provides in Art. 61 that "it shall be prohibited to collect evidence by illegal means" and that "no witness testimony, victims' statements or confessions of the accused that are verified to be obtained by the use of torture or threat, enticement, cheating and other illegal methods, can be used as the basis for deciding cases".

Similarly, the SPPs Criminal Procedure Rules of People's Procuratorates which bind both people's and special procuratorates, also stipulate exclusionary rules, as showed in more articles. First, Art. 140 tells that “... it shall be prohibited to obtain confessions by using torture and threats, enticement, deceit or taking other unlawful methods". Next, Art. 160 states that "... it shall be prohibited to obtain testimony by the means of custody, torture, threats, enticement, deceit or other illegal methods." Then, Art. 265 states that it shall be prohibited to obtain evidence by illegal means and that no suspects' confessions, victims' statements or witness testimony

\footnotetext{
45李柏涛 (LI Botao): 赵作海冤案疑点明显公检法均失职致一错再错 (Obvious Doubts in Misjudged Case ZHAO Zuohai, Errors of the Police, Procuratorates and Courts Leading to More Errors), Xinhua Net, 11 May 2010, available online at <http://china.huanqiu.com/roll/2010-05/ 809896.html>, accessed 31 October 2018.
} 
that had been collected by torture or threat, enticement or other illegal methods can be used as the basis of bringing a charge.

The historical contexts of that law in its changes and reforms are as follows: The Convention against Torture and Other Cruel, Inhuman or Degrading Treatment or Punishment that China joined in September 1988 provides in Art. 12 that "[E]ach State Party shall ensure that its competent authorities proceed to a prompt and impartial investigation, wherever there is reasonable ground to believe that an act of torture has been committed in any territory under its jurisdiction". Accordingly, any Party State to the above Convention, including China that has ratified it, must promptly investigate any allegation of torture.

In the $1996 C P L$, there was an article on evidence, which also stated that it shall be strictly forbidden to collect evidence by the means of tortured confessions, threat, enticement, cheating or by other unlawful means. Since this article was too general without a supporting system, it is just a principled regulation without practical functions. The SPC's 1998 Interpretation on Several Issues in Enforcing the Criminal Procedure Law of the PRC also provided in Art. 61 that it shall be strictly prohibited to collect evidence by illegal means and that no witness testimony, victims' statement or defendants' statements that had been actually verified to use tortured confession or take threat, enticement, deceit or other unlawful means can be used as the basis for deciding cases. The People's Procuratorate's Criminal Procedure Rules also regulated that it should be strictly prohibited to collect evidence by illegal means. The above two judicial interpretations had make more progress than the 1996 Criminal Procedure Law of the PRC, but did not mention how to and when to exclude illegally obtained evidence.

As above demonstrated, the Chinese criminal legislation on the effect of illegally obtained evidence was very simple then. There was no provision on illegally obtained material evidence, and regulations on illegally obtained oral evidence were also diverse among the police, national security organs, ${ }^{46}$ the People's Procuratorates and courts. Thus, the legislative situation brought law enforcement departments many problems, and in the actual operation process of nowhere, with too much discretionary power, led to the departure from each department. In recent years, confessions extorted through torture have led to frequent occurrences of wrongful convictions, detrimental to public confidence with the justice system.

In order to prevent tortured confessions and curb torture as serious injustices in justice practice, SPC, SPP, MOPS, MOSS and MOJ promulgated the Regulation on Several Problems of Excluding Illegally Obtained Evidence in Handling Criminal Cases on June 13, 2010. Its main contents focus on detailed provisions of the illegally obtained evidence, in order to establish exclusionary rules. The $2012 \mathrm{CPL}$ has established legal rules on the exclusion of illegally obtained evidence, as the first act excluding the evidence. The act includes the scope of excluding the

\footnotetext{
${ }^{46}$ They are different from the police. National security authorities handle criminal cases regarding compromising national security and performs the same functions as those of public security authorities by law, whereas the police are responsible for criminal investigation, detention, execution of arrest warrants, and interrogation in criminal cases.
} 
evidence, court examination and legal supervision. Later, relevant judicial interpretations on the Law further define the meaning of tortured confession. The SPC's 2013 Opinions on Establishing Sound Working Mechanisms for Preventing Wrongful Convictions also specify detailed circumstances where to exclude the evidence. Thus, China's criminal evidence system on preventing tortured confessions has basically taken in shape.

\section{The Development and Reforms of Chinese Rules on Evidence Exclusion}

In the set-up of rules excluding evidence in Chinese criminal justice system, such rules were first introduced as a principled article of the SPC's 1998 Interpretation on Several Issues in Enforcing the Criminal Procedure Law of the PRC. Since then, such rules have been subject to further reforms again and again. The 2010 Regulation on Several Issues of Excluding Illegally Obtained Evidence in Handling Criminal Cases delineates the exclusion of the illegally obtained evidence, so as to establish exclusionary rules. Also, the 2012 CPL further improves the rules, both in the form of legislation and for the first time.

\section{The Impact of Exclusionary Rules on the Actors Within Criminal Proceedings}

When first introduced in Art. 61 of the SPC's 1998 Interpretation on Several Issues in Enforcing the Criminal Procedure Law of the PRC, the exclusionary rule had no actual impact on actors in the criminal process. Art. 61 defined the meaning of illegally obtained evidence, clarified its scope and legal consequences, but did not mention specific procedures for excluding it. In practice, Art. 61 cannot be applied as expected, but actually became "law in the paper".

When introduced as an explicit rule in the 2010 Regulation on Several Issues of Excluding Illegally Obtained Evidence in Handling Criminal Cases, the rule details procedures for excluding it, the burden of proof and investigators' presence in court. It signals that the exclusionary rule has been officially established. More importantly than that, the rule can be used by the relevant justice authorities as legal bases in practice. For instance, it imposed the police, prosecutor and courts duties to examine and to exclude illegally obtained evidence at diverse stages of the criminal process. Also, the accused and defence can exercise the right to produce that confession was illegally obtained. Many points on evidence exclusion introduced in the Evidence Rules of 2010 as departmental regulations are later used in the 2012 $C P L$ as a basic law of all criminal procedures and the accused's rights.

When introduced as a legal rule in the first time, the exclusionary rule in the 2012 CPL further recognizes the People's Procuratorates' burden of proof to prove the legitimacy of evidence collection in principle. This rule also establishes the prosecution's standard of proof, such that facts are clear and evidence is reliable and sufficient. Also, the rule includes more actors in the process of applying for excluding illegally obtained evidence. Thus, the party and their defenders or litigation representatives can enjoy the legal right to apply to courts for its exclusion. 
Such legal improvements on its exclusion have promoted the procedural judgement system' gradual formation, with more actors involved in initiating modes, preliminary examination, formal investigation, burden or standard of proof, and remedy means.

\section{The Justification of Exclusionary Rules in Paper Law}

According to the law on the books, justifications of exclusionary rules mainly involve restraints on state power, protection on human rights and procedural justice. The main objectives of the $2012 C P L$ are to punish criminals and to respect and protect human rights. Rights remedy can effectively curb power abuses.

The legal duties of the police, prosecutors and courts to exclude illegally obtained evidence at their respective stage of the criminal process can help find errors sooner, in order to improve the quality of solved cases and to protect suspects' legal rights. ${ }^{47}$ In law, the three institutions should check and restrict each other in the process for the purpose of properly enforcing laws, while cooperating to punish or control crime. In this sense, mutual restraints can promote them to well exclude the evidence from use. Similarly, procedures for the second instance aim to correct errors in the first instance procedures and procedures for the death penalty review aim to mend the flaw made by the former procedures. If the justice system works well, the evidence can be excluded.

\section{The Mandatory or Discretionary Feature of Exclusionary Rules}

There are three kinds of exclusionary rules in China's criminal evidence system. They are respectively mandatory exclusionary rule applicable to illegally obtained oral evidence, discretionary exclusionary rule used for excluding illegally obtained material evidence and correctable exclusionary rule used for tainted evidence as well.

\section{No Acknowledgment of the "Fruit of the Poisonous Tree" Doctrine}

There is no acknowledgment of the "fruit of the poisonous tree" doctrine in China's criminal justice system. One dangerous use of an illegally extracted confession would be to legally allow police to gather leads in finding additional admissible evidence, witnesses, or suspects. The failure to ban derivative evidence can contribute to wrongful convictions. For example, after learning that an accused counterfeiter "may have been beaten before confessing" during his detention, "one Jiangsu prosecutor investigated and decided that the evidence should be excluded" but that a later confession could be used in the trial. ${ }^{48}$ Without "inquiry into the independent voluntariness of a second confession", "there is little to stop further

\footnotetext{
${ }^{47}$ LANG Sheng (ed.), 2012 at 11.

${ }^{48}$ Daum, 2011.
} 
interrogation from becoming a backdoor for admitting illegal confessions". 49 Those who confess once under torture may likely make subsequent false confessions and these confessions will be admitted on the basis that they were not obtained through torture.

\section{The Significance of International Human Rights Law in the Chinese Context}

Notably, international human right law is of significance to human rights progress and justice practice in the Chinese context. As an international citizen, China should abide by all of treaty obligations that it has accepted, i.e., preventing torture or excluding tortured confessions as a party to the Convention against Torture. The prohibition of torture and degrading punishment is also customary. Such obligations universally bind all States, including China that is not a persistent objector. It is obliged not to engage in patterns of gross and flagrant violations of human rights.

But many of rights safeguards are seriously abused in China. They include the right to presumption of innocence, to defence, to legal aid, to a fair trial, to humane treatment, to equality before the law and the principle of ne bis in idem. In practice, the right to a public, independent, and impartial trial, or to appeal is often abused.

\subsubsection{Practice; (High Court) Jurisprudence}

\section{On the Judicial Acceptance of a General "Exclusionary Rule"}

Chinese (High Court) jurisprudence does recognize a general "exclusionary rule" in practice. As many wrongful convictions that were judicially rectified in recent years, local courts have used the exclusionary rule to achieve justice, by law or regulations.

\section{On the Judicial Acceptance of the Duty to Find the Truth}

Chinese (High Court) jurisprudence also acknowledges the duty to find the truth in the name of an effective administration of justice, so as to overrule explicit or implied exclusionary rules. Particularly based on case studies, Chinese courts hardly exclude the illegally obtained evidence by law in most circumstances of recent five years. ${ }^{50}$ In practice, the so-called "illegally obtained evidence" that has been excluded at trial is actually such the evidence that has an illegal form, rather than the evidence that was collected by means against defendants' legal rights. The former evidence usually means that the evidence does not meet the formal elements of legal requirements. But in fact, the most fundamental feature of collecting evidence by illegal means is the violation of the accused's legitimate rights i.e., liberty or property rights protected by the Constitution of the PRC and the CPL. Thus, the

\footnotetext{
${ }^{49} \mathrm{Ibid}$.

${ }^{50} \mathrm{GAO}$ Jie, 2016 at 32.
} 
evidence that was collected by means against the accused's legal rights should be excluded from use as a priority. ${ }^{51}$

\section{The Justifications of Exclusionary Rules and Their Application in Specific Cases}

The justification(s) of exclusionary rules include the legality of evidence collection and justice in each case, whereas in particular cases their application is often limited to accurate and sufficient evidence of tortured confession during interrogations. For example, evidence can be excluded only in cases where recordings show investigators' making interrogation transcripts or audio-video recordings not in the actual trial time, and also prosecutors failed to prove the means of collecting evidence legitimate, and the relevant investigator cannot make a reasonable explanation on them.

For instance, in what was called the first case of excluding illegally-obtained evidence in China, legal commentators have noted that differences between the decision at the initial trial and the decision at appeal of the bribery case of ZHANG Guoxi revolve around critical issues. These issues are the distinction between illegal and defective evidence, the "range" of exclusionary rules, what constitutes "other illegal means of evidence collection" and the degree of proof necessary to demonstrate that evidence was obtained illegally. After the initial trial in 2011, the prosecution lodged a protest against the trial judgment, which excluded evidence on a guilty plea provided by the prosecution. Based on new evidence from new witnesses provided by the prosecution, the decision to exclude the confession and the evidence of other witnesses was reversed on appeal in July 2012. The final judgment stated that ZHANG Guoxi's "confession of guilt was not made under inquisition by torture" and that the prosecution "sufficiently proved the legitimacy of his confession obtained by investigative organs", so that "his pre-trial confession of guilt can be admissible as evidence". 52

\subsubsection{Consequences of a Violation of Exclusionary Rules}

In the $2012 C P L$, remedies for violating the exclusionary rules are absent. In practice, the most needed remedies for consequences of breaching the rules appear in three main situations: (1) When the defence is dissatisfied with the ultimate non-initiation of the procedure for excluding illegal evidence, after providing the evidentiary material required for starting the procedure and reaching the degree under which another rational judge would have "reasonable doubts" as to the

\footnotetext{
${ }^{51}$ YANG Yuguan, 2015 at 395.

52祝优优陈佳玮 (ZHU Youyou/CHEN Jiawei): “中国非法证据排除第一案”终审遭遇大逆转 (The Final Trial of the First Case of 'Excluding Illegal Evidence in China' Suffered from A Big Reversal), Fenghuang Net, 25 July 2012, available online at <http://news.ifeng.com/mainland/ detail_2012_07/25/16269272_0.shtml>, accessed 31 October 2018.
} 
legitimacy of evidence; (2) When the defence continues to refuse to accept the court's decision not to exclude evidence after the court's final review; (3) When the prosecutor refuses to accept the court's decision to exclude potentially illegal evidence in court. The absence of effective remedies demonstrates how the institutions of Chinese criminal justice system are set against the accused.

\subsubsection{Debate on Exclusionary Rules (in Civil Society, etc.)}

\subsubsection{The Public Debate on Exclusionary Rules}

There are many public debates on chances, impactor(in) effectiveness of exclusionary rules in Chinese criminal justice system. Debates continue as to the effects of exclusion. For example, relevant laws or regulations clearly state that illegal oral evidence cannot be the basis of conviction, for approving arrest or for indictment, ${ }^{53}$ but it remains unclear whether it can be used for other purposes, such as at sentencing.

Some critics hold that there is an obvious shortcoming because while coerced oral statements cannot be used at trials, physical and documentary evidence derived from such statements can be used as evidence. The definition of illegally obtained testimony only refers to "statements by criminal suspects or defendants obtained through illegal means such as forced confessions as well as witness testimony or victim statements obtained through illegal means such as the use of violence or threats". ${ }^{54}$ This law has been interpreted, contrary to the intent and plain meaning of Art. 43 in the 2012 CPL, so that evidence collected by enticement, deceit and some other illegal means is not excluded. ${ }^{55}$

Also, the above debates appear even in individual cases. For instance, the first controversy in case ZHANG Guoxi revolved around a distinction between illegal and defective evidence, particularly in the original judgment. Illegal evidence is evidence collected via serious violations of human rights. Defective evidence, on the other hand, is evidence that is collected in a manner that, while not in complete accordance with proper forms or procedures, does not involve human rights violations. ZHANG Guoxi's lawyers claimed that investigators' extended inquiry into ZHANG Guoxi's corruption during the preliminary investigation, before criminal proceedings commenced, constituted illegal detention that seriously violated the basic human rights of the accused. ${ }^{56}$ The judgment at trial agreed with this reasoning and excluded ZHANG Guoxi's confession of guilt. This decision was

\footnotetext{
${ }^{53}$ Art. 2 of the Rules.

${ }^{54}$ Art. 1 of the Rules.

${ }^{55}$ Art. 43 of the $C P L$.

56姚培硕 (YAO Peishuo): 刑法非法证据排除条款困境: 侦查人员自证清白 (The dilemma of Exclusionary Clauses on Illegal Evidence in Criminal Law: Investigators Testifying Own Innocence), The Beijing News, 2 August 2012, available online at $<\mathrm{http}: / / \mathrm{www}$.chinanews.com/fz/ 2012/08-02/4077216.shtml>, accessed 31 October 2018.
} 
reversed on appeal because new evidence was introduced by the prosecution which demonstrated that ZHANG Guoxi's confession had not been extracted via torture. ${ }^{57}$ In this sense, the detention was found not to be a serious violation of human rights, so the confession was merely defective evidence, not illegal evidence.

The second controversy in case ZHANG Guoxi was about the effective "range" of exclusionary rules, that is, whether evidence collected during preliminary investigations can be illegal evidence. The trial court excluded the use of his pre-trial confessions as the basis for convictions, ${ }^{58}$ suggesting that the "range" of evidence to exclude should not be limited to the investigation stage, even if the acquisition of illegal evidence occurred before the investigation and ended when the criminal trial began. Exclusionary rules should be applied broadly to all cases where there is a causal relationship between the conduct of illegal collection and the evidence. In fact, the interrogation transcripts, key evidence in the case, did not result from interrogation after taking criminal compulsory measures, but from prior intensive interrogation by investigative organs. One ground on which the trial court's decision was reversed on appeal was that the Rules do not explicitly provide for the exclusion of evidence collected during preliminary investigations. This regulatory silence can only lead to miscarriages of justice based on faulty evidence. If evidence is collected illegally, it should be excluded as illegal evidence no matter when it was collected.

The third issue in case ZHANG Guoxi revolved around what the Rules mean when they refer to "other illegal means". Confessions made by suspects who have been deprived of sleep, food or other essentials should be excluded along with the typical confessions extorted under torture. Regrettably, when the defence party argued for the exclusion of evidence obtained by means of forced confessions, sleep deprivation, threats, enticements, deceit or other underhanded means used to obtain confessions of guilt, only the first was adopted as a reason to exclude evidence. The other methods were "strategically" declined by the court. ${ }^{59}$ Continuous ill treatment, however, can be similar to torture because the accused's spirit is broken along with the accused's body. Methods like sleep deprivation are inhumane procedures are serious violations of citizens' basic human rights. Since the $C P L$ stipulates that a "summons term", that is, the length of time a witness can be held at the pleasure of an investigatory body, shall not exceed $12 \mathrm{~h},{ }^{60}$ overtime questioning of an accused should be regarded as ill treatment or an "oppressive atmosphere", particularly

\footnotetext{
57积优优陈佳玮 (ZHU Youyou/Zhu \& CHEN Jiawei): “中国非法证据排除第一案”终审遭遇 大逆转 (The Final Trial of the First Case of 'Excluding Illegal Evidence in China' Suffered from A Big Reversal), Fenghuang Net, 25 July 2012, available online at <http://news.ifeng.com/ mainland/detail_2012_07/25/16269272_0.shtml>, accessed 31 October 2018.

58 孔令泉 (KONG Lingquan): 国内非法证据排除第一案 (The 'First Case' of Excluding Illegal Evidence in China), Democracy and Legal System Times, 25 April 2012, available online at $<$ http://news.ifeng.com/opinion/special/xieyalongfanan/detail_2012_04/25/14152917_0.shtml>, accessed 31 October 2018.

${ }^{59} \mathrm{Ibid}$.

${ }^{60}$ Art. 126 of 2012 CPL.
} 
when "necessary diet and rest time" like three meals and continuous rest of no less than six hours within a 24-h are also denied. ${ }^{61}$ China should adopt rules similar to those of countries like Canada, where confessions extracted in "oppressive atmospheres" are excluded and also define the crime of torture as a matter of priority in accordance with Art. 1 of $C A T$, with penalties commensurate with the gravity of torture. $^{62}$

Concerning the fourth issue, the burden of proof, the prosecution should bear the burden of proving the legitimacy of evidence. In other words, the prosecution should adduce evidence to prove that a confession was not collected illegally to the level of "beyond a reasonable doubt". Where the prosecution cannot satisfy this degree of proof, with significant doubts remaining about the possibility that illegal methods were used to obtain evidence, illegal evidence should be recognized and excluded under the principle that it is doubtful evidence. In case ZHANG, the trial court upheld this principle, to the benefit of the accused, but the appeal court overturned the trial court's judgment, ruling that the prosecution "sufficiently proved the legitimacy of his coerced confession" such that the trial judge should have included the "pre-trial confession of guilt ... as evidence", 63 without considering whether the confession was not obtained through torture "beyond a reasonable doubt". This disregard for the "reasonable doubt" standard implies that 'abuse of discretion' by a court leaves much room for the inclusion of evidence obtained illegally.

In critical commentaries, almost all legal professionals have agreed that China's exclusionary rules have "not been strictly implemented". 64 ZHANG Jun, the Vice-President of the SPC, criticized defence lawyers because, as of early 2011, he was unable to find any cases in which a lawyer had successfully excluded DNA evidence on the grounds that it had not been properly collected. ${ }^{65}$ Lawyers claim that this situation derives from their long practice "in a system emphasizing substantive over procedural justice", in which they focus "predominately on factual arguments". ${ }^{66}$ As indicated by a recent survey, approximately only $20 \%$ of defence

\footnotetext{
${ }^{61}$ United Nations Commission on Human Rights, 'Report of the Special Rapporteur on torture and other cruel, inhuman or degrading treatment or punishment, Manfred Nowak. Sixty-second session (10 March 2006)' E/CN.4/2006/6/Add.6 (2006), available online at <http://www.refworld.org/ docid/45377b160.html>, accessed 31 October 2018.

${ }^{62}$ See footnote 61

63聚焦 “非法证据排除” 第一案: 疲劳审讯算不算逼供 (The Focus of 'First Case of Excluding Illegal Evidence in China': Whether Fatigue in Investigation is Torture or not), China Youth, 3 September 2011, available online at <http://news.xinhuanet.com/legal/2011-09/03/c_121958850. htm>, accessed 31 October 2018.

${ }^{64}$ 任芳 (REN Fang): 非法证据排余原则未严格执行亟待律师激活避免冤错案 (The Principle of Evidence Exclusion Has Not Been Strictly Implemented), cnr.cn, 10 January 2011, available online at $<\mathrm{http}: / / \mathrm{www} . c n r . c n / c h i n a /$ newszh/yaowen/201101/t20110110_507564061.html>, accessed 31 October 2018.

${ }^{65}$ Daum, 2011.

${ }^{66}$ TIAN Wenchang.
} 
attorneys had attempted to invoke the Rules,${ }^{67}$ even though mounting a procedural defence is legally "an obligation performed by lawyers to protect judicial fairness". ${ }^{68}$ Moreover, the lawyers who most frequently attempt to invoke the Rules are often frustrated by judges' lack luster responses to their advocacy, such as ignoring their request, contrary to Art. 5 of the Rules, for the examination of allegations of illegal evidence. ${ }^{69}$ Lawyers also found that judges were often unwilling to debate whether evidence was collected illegally, even if inquiries into the propriety of evidence were initiated following written motions. ${ }^{70}$ The failure of the Rules is best exemplified by Case FAN Qihang. In that case, the Rules were not invoked in Mr. FAN's favour until the SPC reviewed his death sentence, even though Mr. FAN and his lawyers had repeatedly protested that his confessions were false and had been extracted under torture. His lawyer 'publicly released and submitted to the court clandestine videotapes of Mr. FAN discussing his treatment and displaying scars on his arms', but the SPC, the court of final appeal for death sentences, never permitted the defence to use this video. The SPC conducted the trial behind closed doors, and the only way that Mr. FAN was able to participate in the process was by being executed for his "crime". ${ }^{71}$

\subsubsection{The Role of the International Monitoring Bodies' Report on the Debate}

The reports of the international monitoring bodies have played an essential role in Chinese debates to a certain degree. For instance, the Committee Against Torture is the body that monitors implementation of the Convention against Torture and Other Cruel, Inhuman or Degrading Treatment or Punishment (CAT), and the Human Rights Committee monitors implementation of the ICCPR. China as a party to CAT and to the ICCPR is obliged to submit regular reports on implementation of them. Treaty bodies examine each report and address concerns and recommendations in the form of "concluding observations".

The expansive protection of the accused from torture in China has been greatly inspired by the definition of "torture" in CAT. Particularly in the context of the current $2012 C P L$, illegally collecting evidence by the means of torture or other illegal acts refers to the use of corporal punishments, disguised corporal punishments or other physical or mental suffering in a physically or mentally painful way in order to force the accused to confess against his or her willingness. Accordingly, "torture" was not a mere label any more, but has physical pains or mental suffering

\footnotetext{
${ }^{67}$ YANG/ZHANG, 2010.

${ }^{68}$ See footnote 66 .

${ }^{69} \mathrm{Ibid}$.

${ }^{70} \mathrm{Ibid}$.

${ }^{71} \mathrm{Ibid}$.
} 
as the standards for determining which illegal acts constitute "torture" in the context of CAT, and also has forcing the accused to confess against willingness as the essence of torture. $^{72}$

\subsubsection{Institutional Arrangements Securing Exclusionary Rules}

1. There are many institutional arrangements on securing individual rights in China's criminal justice system. They mainly include cautioning or informing the accused of his or her rights, access to his or her lawyer and application for medical surveillance, as mentioned in the current $2012 \mathrm{CPL}$.

2. Unfortunately, it is still short of an effective remedy for appeals on the ground of a violation of an exclusionary rule in law. Thus, those facing the risk of rights violations can hardly find a way to remedy or correct the above violation in practice.

3. Only law enforcement authorities including the police, prosecutors and courts actually control whether to respect limitations of fact-finding. Benefit like promotion or awards can be obtained from extorted confession through torture or guilty plea.

4. In law or practice, there is no essential interest of such actors in limiting fact-finding. They often seek substantive justice and not procedural justice in order to achieve the goal of crime control and even a very-high or almost-full conviction rate.

\subsection{Exclusion of Evidence Obtained by Torture}

\subsubsection{Definitions of Torture and Degrading Punishment}

One of major differences between Chinese legislation and international standards are related to the definition of torture. The $1997 C L$ punishes those torturing suspects and the accused in the criminal process only, whereas in the definition of CAT, torture applies to any process.

In legislation, the 1982 Constitution, Law on Prisons adopted in 1994, Law on State Compensation adopted in 1994, People's Police Law adopted in 1995 (1995 PPL), ${ }^{73}$ Judges Law adopted in 1995, and the 2012 CPL effective 2013, and the $1997 C L$, are primary legal safeguards against torture as 'a criminal act'. ${ }^{74}$

\footnotetext{
${ }^{72}$ CHEN Ruihua, 2015.

${ }^{73}$ Its Art. 33 stipulates: '[A] people's policeman has the right to refuse to carry out any directive that exceeds the mandate of the people's police as defined by laws and regulations and, at the same time, has the right to report such a breach to a higher authority.' This appears to effectively 'prevent anyone from citing a superior's order as a pretext for using torture'.

${ }^{74}$ CAT Report, 1996a at paras. 6 and 7.
} 
Moreover, the $1997 C L$ attaches importance to the prohibition of the crime of torture. It includes retention 'of the crime of extorting confessions by torture and the crime of physically abusing prisoners' and 'introduction of the crime of the use of force by judicial personnel to extract testimony'. ${ }^{75}$ It explicitly stipulates 'that those who extort confessions by torture, extract testimony from witnesses by force or physically abuse prisoners shall be punished more severely'; and those 'who cause injury, disability or death through the above three crimes shall be sentenced to death, life imprisonment or fixed-term imprisonment of not less than 10 years. ${ }^{, 76}$

More importantly, the $1997 C L$ introduced the crime of extracting testimony by force and amended 'the punishment given to those who cause death through extortion of confessions by torture', 'the provisions on the applicable charges and punishment for persons who cause injury, disability or death through unlawful detention' and 'on the applicable charges and punishment for abuses of prisoners that cause injury, disability or death'. ${ }^{77}$ This appears to aggravate relevant punishments to prohibit torture.

\subsubsection{Definitions of Right to Remain Silent/Privilege Against Self-incrimination}

In China, there is no statutory rule or constitutional rule on the right to remain silent, but are statutory rules on privilege against self-incrimination only. But China needs to enshrine the right in its legislation in order to better protect human rights. The ICCPR addresses both the right to remain silent and privilege against self-incrimination, as a major international human rights treaty that China has signed but not yet a State party.

Art. 118 of the $2012 C P L$ retains the provisions that require suspects to truthfully answer investigators' questions, implying that suspects have no right to remain silent when being questioned. These provisions are especially important to prosecutors, given investigators' dependence on confessions. But since legislators have retained these provisions in the systemic context of the Amendment, it is necessary to adopt an interpretation that preserves the right to silence. One possible interpretation is that the law allows the accused to remain silent but requires them to tell the truth if they waive that right. In other words, in the 2012 CPL there might be the right to silence, but no right to lie. The institutions of the Chinese justice system do not yet recognize the right to silence and this deficiency needs to be rectified.

It is worthy of note that no article in the $2012 C P L$ explicitly articulates criminal suspects' right to silence, including the closest Art. 50, and thus many legal scholars in China do not consider this right to be fully established. Even if Chinese law has

\footnotetext{
${ }^{75} \mathrm{Ibid}$. at para. 8 .

${ }^{76} \mathrm{Ibid}$. at para. 8 .

${ }^{77}$ Ibid. at para. 14 .
} 
already established an implied right to silence, there is still a long way to go before the ideal system is transformed into the real one.

First, the legislature and judiciary should clarify the right of suspects and the accused to remain silent under interrogation when they implement the interpretative regulations of the $2012 C P L$.

Second, any later amendment to the $C P L$ should remove the requirement that suspects and the accused should truthfully answer police questions. While proper interpretation can reconcile Art. 118 with the presumption of innocence, it is still too open to misinterpretation. Art. 118 should be revised by removing the provision that suspects should truthfully answer questions from investigators, so as to fully embody the principle of the presumption of innocence.

In this case, the current $C P L$ could be modified as follows: "[A]ny person should be presumed innocent before proved guilty by the People's Court in accordance with the law". These few words would clarify a principle that is already essentially embodied in the $C P L$ and would immediately improve China's international image and status. If the words are faithfully followed to counteract institutional obstacles, they would constitute one of the greatest advances in the promotion of justice and in the adoption of the rule of law in China's history. Given China's population and global influence, they would also constitute a significant advance in the struggle for international human rights recognition.

\subsubsection{Exclusionary Rules for Evidence (Possibly) Obtained by Torture}

\subsubsection{Legal Framework}

1. As a part of the legal framework governing the exclusion of evidence in the case of (possible) torture or degrading treatment, the 2012 CPL improves the exclusionary rules for illegally obtained evidence and also requires recording of certain interrogations.

Concerning direct prohibitions on torture or degrading treatment, the $2012 \mathrm{CPL}$ explicitly barred "extorting confession[s] by torture, or gather[ing] evidence by threat, enticement, deceit or other illegal means, or to force anyone to commit self-incrimination" in Art. 50. The 2012 CPL codified a specific exclusionary rule for confessions obtained by torture or other illegal means, i.e., in Art. 54. Moreover, it explicitly requires the exclusion of confessions from suspects and accused that have been extracted by torture or other illegal methods. They also exclude witness testimony and victims' statements collected by means of violence, threats and other illegal methods, as well as physical and documentary evidence that is collected against the law and that seriously affect trial fairness.

In the $2012 C P L$, Art. 121 specifically requires an audio or visual record of an interrogation be kept in any cases involving those facing life imprisonments or the 
death penalty. Different from mandatory exclusion, Art. 121 also authorizes and not requires investigators to do so in other cases. There is also a new basic interrogation rule in Art. 116. Art. 116 further requires investigators of the People's Procuratorate or the public security authority to conduct an interrogation of criminal suspects and also provides that such interrogation should be done in a jail after a suspect has been transferred to a jail.

But in fact, the 2012 CPL still imposes the legal duty to objectively and fully provide evidence on those involving in or having information of a case. Accordingly, such citizens or suspects might be required to assist investigation even by any means.

Furthermore, some regulations also constitute a major part of the above framework. For example, the SPC's 2013 Notice on Establishing and Improving Working Mechanisms for the Prevention of Miscarriages of Justice in Criminal Cases simply excludes confessions obtained through torture or other illegal methods. Accordingly, Chinese courts should not convict the accused based on confessions alone, but should exclude the use of confessions collected by the means of torture or other illegal methods, i.e., cold, hunger, bright light, heat, fatigue of the accused. Except in cases of emergency when on-site interrogation must be adopted, courts should exclude the use of confessions, made outside the required place, confessions, not wholly audio-video recorded by law or confessions, obtained by measures without being excluded the possible use of illegal methods during interrogation.

2. Both Chinese legislation and regulations address special procedures for screening investigations conducted by torture or other illegal means. Among them, the 2012 CPL stipulates the obligation of the PPs, courts and the police to exclude illegally obtained evidence, along with the procedure of investigation for its exclusion in court hearings. In the trial process, the relevant PPs shall prove at trial or in appeal that all evidence was collected legally. Courts will be able to command investigators or other personnel to appear in court and explain how they collected evidence in interrogation. By the law, upon notice, investigators will also have to appear in court to justify their methods. Indeed, some investigators are already proactively demonstrating the legality of the evidence that they have collected before it is challenged.

Moreover, the SPP mentions the special procedures in its Notice on Issuing the Guiding Opinions of the SPP on the Application of the Provisions on Several Issues concerning the Examination and Judgment of Evidence in Death Penalty Cases and the Provisions on Several Issues concerning the Exclusion of Illegal Evidence in Criminal Case. Art. 7 of the Notice requires procuratorial organs to strictly implement the synchronized recording system in the whole process of interrogation of duty-related criminal suspects. Art. 7 further states the accountability system that when "any adverse consequence is caused due to any failure to strictly implement 
the relevant provisions or falsehood in the implementation, the major liable persons shall be investigated and punished according to the relevant provisions". ${ }^{78}$

Discretionary audio or video recording of interrogations, i.e., in cases without involving the punishment of life imprisonment or the death penalty, as an essential adjunct to transcripts of interrogations in procedure can be found in more regulations. For example, the SPC, the SPP, MOPS, MOSS, MOJ, and LAC (the Legislative Affairs Commission of the Standing Committee of the National People's Congress) jointly issued their Provisions of Several Issues on the Implementation of the Criminal Procedure Law following the adoption of the 2012 CPL. The Provisions explicitly include the procedural requirement, such that "where investigators keep an audio or visual record of the interrogation process, it shall be indicated in interrogation transcripts". ${ }^{79}$

Similarly, the MPS'2014 Notice on Working Rules of Public Security Organs on Audio-visual Recording of Interrogation of Suspects requires mandatory recording of interrogations applicable to several kinds of serious criminal cases in Art. 4. They are potentially capital cases, cases of "serious injury or death, serious harm to public safety or serious violation of civil rights", or involving organised crime, serious drug crimes, and of "other intentional crimes that can be sentenced to ten years in prison by law".

The MOPS'2014 Notice also specify special procedures for and the mandatory scope of interrogation recordings in Art. 3. Accordingly, they "shall include the whole process of each interrogation and be uninterrupted, to maintain the integrity and shall not be selectively recorded, edited or deleted". In this context, "interrogation" broadly involves interrogating the accused in law enforcement facilities, at detention houses or at suspects' homes when they are not detained. The mandatory scope of such recordings is even expanded to "on the scene" questioning in an emergency. In addition, Art. 16 of the above Notice also provides that individuals other than interrogators are responsible for maintaining custody of the recordings.

The Notice also details pre-recording checks of the equipment, when recording should start, the frame coverage and camera angle, in Art. 9, and the identification on the record of evidence in Art. 11. It further requires such details as "time, place, modus operandi, tool of criminal purpose, state of victim(s), subjective state of mind and other key facts involved with the crime" be transcribed exactly as showed in the confession recording, in its Art. 13.

\footnotetext{
${ }^{78}$ Notice of the SPP on Issuing the Guiding Opinions of the SPP on the Application of the Provisions on Several Issues concerning the Examination and Judgment of Evidence in Death Penalty Cases and the Provisions on Several Issues concerning the Exclusion of Illegal Evidence in Criminal Cases, No. 13 [2010] (30 December 2010), available online at <http://www. lawinfochina.com/display.aspx?lib=law\&id=8745\&CGid=>, accessed 31 October 2018.

${ }^{79}$ Para. 19 of the Provisions of the SPC, the SPP, the MOPS, the MOSS, the MOJ, and the LAC on Several Issues concerning the Implementation of the Criminal Procedure Law, (26 December 2012), available online at <http://www.lawinfochina.com/display.aspx?lib=law\&id= 13295\&CGid=>, accessed 31 October 2018.
} 
3. According to the law on books, the justifications for the exclusionary rules mainly include respecting and safeguarding human rights, ensuring justice in each criminal case and the reliability of tortured confessions as well.

4. The above exclusion rules are mandatory in principle as indicated in Arts. 50, 54-57 of the $2012 C P L$, but appear to be discretionary in the cases of collecting material or document evidence by illegal means as exceptions in Art. 54 of the law. Specifically, Art. 50(2) of the law requires strictly prohibiting investigators from extorting confessions by torture and from collecting evidence by threat, enticement, deceit or other unlawful means. The provision implies that any form of evidence collected by the illegal means should be excluded from use in principle. Art. 54(1) of the law further states that "[C]onfessions of the criminal suspect or defendant extorted by torture or other illegal means, testimonies of the witness and statements of the victim collected by violence, threat or other illegal methods shall be excluded." So, the above rules are mandatory in principle, particularly in the case of such confession.

Art. 54(1) of the 2012 CPL also states that "[W]here the material evidence or documentary evidence is obtained against the legally prescribed procedure, which may severely impair the judicial impartiality or justice, supplements and corrections, or reasonable explanations shall be made; if the above-mentioned measures cannot be taken, the said evidence shall be excluded." Thus, not all of material evidence or documentary evidence collected by illegal means like torture can be excluded by law. Only if such evidence may severely impair justice and also no supplement, correction or reasonable explanation on its illegal means is available, the mandatory scope of the exclusionary rules should include the evidence. Otherwise, exclusion is discretionary.

\subsubsection{Practice; (High Court) Jurisprudence}

In practice, Chinese courts recognize a general "exclusionary rule" in the cases of possible torture, in order to safeguard human rights or seek for justice. Particularly given unreliability of a confession or other statement, many courts have begun to initiate the procedure for excluding illegally obtained evidence by law in recent years.

Also, the courts often read the duty to find the truth into a specific rule in order to overrule any explicit or implied exclusionary rules in China's justice practice. According to Art. 118 of the 2012 CPL, the accused should "answer investigators' questions truthfully" and also they should inform him or her that confessing truthfully may be treated mercifully, so that confession is encouraged to find the truth in law. On the one hand, the difficulty of changing the traditional idea of "confession first", leaving facts and evidence as the second against both law and justice, partly results from the usual policy of leniency for those who confess his or her guilt. As early as in the SPP's 2010 Notice, the SPP urges courts to make wholesale changes on confession in their traditional judicial attitude. Courts "shall 
attach great importance to evidence and investigation and research, practically change the idea of "confessions first", and "to the examination and use of physical evidence. If there is no other evidence except for the accused's confession, no defendant can be found guilty". 80

On the other hand, the $2012 C P L$ allows interrogators to remind suspects of their legal duty to "answer investigators' questions truthfully" and of the benefit from their truthful confession in order to seek the truth at the cost of justice and human rights. Only with the legal duty as an incentive to find the truth, Chinese courts and judges would usually exercise their discretion to overrule the exclusionary rules in practice in order to control crime and maintain social stability in the name of substantive justice.

\subsubsection{Exclusionary Rules in Public Debate}

The 2012 CPL have once again made the use of illegally obtained evidence a point of controversy amongst domestic and foreign legal experts. Supporters of the new law claim that it is a revolutionary step towards the elimination of the use of illegally obtained evidence, ${ }^{81}$ while critics of the law argue that it will not lead to any substantial change but could even make the situation worse. ${ }^{82}$ Almost daily, some pundit decries the high human cost of wrongful convictions while another pundit intones about the dangers of allowing dangerous criminals to go free due to evidentiary technicalities. Both sides impugn the wisdom of the legislature, alternatively excoriating its harshness and its leniency. The resulting law is a complex mosaic of political compromises.

\subsubsection{Institutional Arrangements Securing the Ban on Torture}

In China, institutional arrangements appear to respect for prohibiting torture, particularly given that the relevant law can protect the accused's access to lawyers or appeals on the ground of tortured confession.

Specifically, the 2010 State Compensation Law (2010 SCL) imposes a duty on detention facilities to demonstrate no mistreatment on a wrongfully convicted

\footnotetext{
${ }^{80}$ Notice of the SPP on Issuing the Guiding Opinions of the SPP on the Application of the Provisions on Several Issues concerning the Examination and Judgment of Evidence in Death Penalty Cases and the Provisions on Several Issues concerning the Exclusion of Illegal Evidence in Criminal Cases, (30 December 2010), available online at $<$ http://www.lawinfochina.com/display. aspx?lib=law\&id=8745\&CGid=>, accessed 31 October 2018.

${ }^{81}$ See Time, 2012 at 144.

${ }^{82}$ See Joshua Rosenzweig, Flora Sapio, Jiang Jue, Teng Biao and Eva Pils, 'The 2012 Revision of the Chinese Criminal Procedure Law: (Mostly) Old Wine in New Bottles', CRJ Occasional Paper, 17 May 2012, available online at <https://papers.ssrn.com/sol3/papers.cfm?abstract_id=2462686>, accessed 31 October 2018.
} 
prisoner. This reform is intended to discourage authorities from torturing or otherwise mistreating suspects and would help to curb torture and ill-treatment in detention.

Concerning preventing torture of suspects, the $2012 \mathrm{CPL}$ has made clear that confessions extorted through illegal means, such as torture, and witness testimony and depositions of victims obtained illegally, such as by violence or threats, should be excluded from use. To institutionally prevent extortion of confession by torture, it has regulated that suspects be sent to a detention facility for custody after being detained or arrested and be interrogated there, apart from the audio or video-taped process of interrogation. Revisions on ruling out illegal evidence and strictly regulating the procedure of collecting evidence are designed to effectively curb torture.

Furthermore, the new procedure allowing courts to call investigators to explain the legality of evidence (amended Art. 56), to call on prosecutors to provide evidence of the legality of evidence (amended Art. 55), and to require a witness statement to be examined and verified in court before it can serve as the basis for deciding a case (amended Art. 59), is intended to safeguard the right of a defendant and his or her lawyers to apply to the court for excluding evidence illegally gathered as they allege, in amended Art. 56. Both evidence provisions and exclusionary rules have been regarded as instrumental in changing a situation from that 'the confession is king' (证据为王 Zhengjuwei Wang), to the proper relation between material evidence and oral statements, of which the latter should be completely relied on.

In 2006, the SPP issued "Directives to Eliminate Interrogation through Torture", which requires that People's 'Procuratorates throughout China begin audio and video taping police interrogations in some cases to prevent coerced confessions'. ${ }^{83}$

Concerning appeals, the Chinese criminal justice system, in practice, does not appear to effectively protect an accused, even if he or she is persistent in claiming his or her factual innocence.

But the law enforcement authorities usually seeking for crime control by any means are legally endowed the power to control whether limitations of fact-finding are respected. Such limitations are often against the authorities' common goal of crime control. Also, they often benefit a lot from the high rate of conviction based on confession and have no real interests to limit fact-finding in handing criminal cases. If the detection or punishment rate is low in ranking, crime control authorities would be punished by less financial support, fewer human resources or no promotion of leaders. On the contrary, high or almost-full rates often bring more benefits in many aspects. It is not only a question of honour, but also means more funds, promotion or awards.

The $2012 C P L$ contain some loopholes and other defects which will frustrate their intent and damage the exclusion of illegally obtained evidence. A major defect

\footnotetext{
${ }^{83} \mathrm{See}$ Bureau of Democracy, Human Rights, and Labor, 'Country Report on Human Rights: China (includes Tibet, Hong Kong, and Macau)' (11 March 2008), available online at <http://www.state. gov/j/drl/rls/hrrpt/2007/100518.htm>, accessed 31 October 2018.
} 
is on unfair burdens of proof, frequently imposed on the accused. The law imposes an onus on the prosecution to demonstrate that evidence was not collected through torture. This recognizes that it would be very difficult for the accused to show that he or she was tortured, but the provision is nonetheless flawed because the prosecution often has no better knowledge of what occurred during interrogation, which is in most cases was not conducted by the prosecution but by the police. This again points to the need for institutional reforms to ensure that the police who conduct interrogations are present and can answer for their conduct at trial.

Who bears the burden of proof in practice in China is not uniform. Sometimes it is borne by the PPs, sometimes by the PCs and, in the worst cases, simply by defence. $^{84}$ The common law voluntariness rule is more protective of the accused in those countries. Consistent with the presumption of innocence, it requires the prosecutor to prove beyond a reasonable doubt that the statement was voluntary.

Hence, the following institutional improvements are necessary. First, existing legal and judicial interpretations only provide for "strictly prohibiting extorted confessions by torture and collecting evidence by illegal means of threat, enticement, deceit or other methods". This narrow approach leaves many loopholes through which injustice can pass. To close these loopholes, further clarification of such concepts as "extorted confessions by torture", "threat", "lure" and "deceit" is necessary, and what constitutes "other methods" should be further defined in order to enhance the operability of the provision. Second, regarding the procedure for exclusion of illegal evidence, exclusionary rules should be considered as a right of criminal suspects and defendants. Such rights should limit investigative powers and protect the right of the accused to a fair trial. Where the defence applies for the review process but the court refuses to start it, or where the defence is dissatisfied with the outcome made by the court after the process, the defence and prosecution parties should be entitled to express objections as a relief right. On this basis, if the accused refuses to accept court judgements or the prosecution believes definite errors exist in the first-instance court's decision on illegally obtained evidence, either party could object them at appeal. Appeal courts should review the defence's appeal and the prosecution's protest. ${ }^{85}$ Only in this way can the procedural rights of both parties can be effectively protected.

\footnotetext{
${ }^{84}$ 刘梦月、杜晓 (LIU Mengyue/DU Xiao): 乐至原交通局长受贿“大闹” 公堂 (Former Lezhi County Head of Transportation Ministry, Accused of Accepting Bribes, and Creates Spectacle in Court), People Net, 20 January 2011, available online at <http://fanfu.people.com.cn/GB/ 13777390.html>, accessed 31 October 2018.

${ }^{85}$ Art. 218 of the 2012 CPL states that "[A]gainst a sentence of a local people's court at any level as a court of first instance, a victim or his or her legal representative shall, within five days after receiving a written sentence, have the right to request that the People's Procuratorate file an appeal. The People's Procuratorate shall, within five days after receiving the request of the victim or his or her legal representative, make a decision on whether to file an appeal and make a reply to the requesting party."

Its Art. 222 also states that "[T]he people's court of second instance shall conduct a comprehensive review of the facts found and application of law in the sentence of the people's court of first instance, without limitations to the extent of appeal.".
} 


\subsubsection{Admissibility of Indirect Evidence ("Fruits of Poisonous Tree") in Cases of Torture}

\subsubsection{Legal Framework}

China's criminal justice system does address the problem of indirect evidence gained from torture, but not acknowledge a "fruit of the poisonous tree" doctrine in statutory rules. In practice, there is no way to apply such rules that have no legal basis and clearly go against the law enforcement authorities' common goal of crime control.

\subsubsection{Practice; (High Court) Jurisprudence}

Justifications for the non-application of "fruit of the poisonous tree" in China include both very complex situation of evidence collection and many difficulties of excluding typical involuntary confession in the current judicial environment of the PRC. ${ }^{86}$

\subsubsection{Effect of International Law (Human Rights)}

Both CAT and the ICCPR as major international human rights treaties have an impact with regard to the ban on "torture evidence", as detailed above. ${ }^{87}$ After ratifying CAT, China has taken diverse measures to reform the evidence system of prohibiting or preventing torture. Following ratifying the ICCPR, China further improves its human rights protection in procedure. All of efforts to revisions on Chinese criminal law and criminal procedures are mainly based on such international standards as the effect of international law on China.

\subsubsection{Remedies Following Violations of Exclusionary Rules}

There are special procedures for initiating the application for excluding with regard to a possible violation of the ban on torture, and no remedy for a violation of exclusionary rules safeguarding the ban on torture in the PRC.

In PRC's criminal justice system, there is a standard procedure for testing confessions or other statements for "torture stains" or trace. ${ }^{88}$ As showed in Arts.

\footnotetext{
${ }^{86}$ See GAO Jie, 2016 at 32; LIN Guoqiang, 2013 at 182, 183.

${ }^{87} \mathrm{See}$ above 2.1.1.2 (3) and 3.1.1.1.

${ }^{88}$ In the 2012 CPL, Art. 55 states that "[A]fter receiving a report, accusation, or tip on any illegal obtainment of evidence by criminal investigators or after discovering any illegal obtainment of evidence by criminal investigators, a People's Procuratorate shall conduct investigation and verification. If it is confirmed that evidence has been illegally obtained, the People's Procuratorate shall provide an opinion on correction; if any crime is committed, criminal liability shall be investigated in accordance with law." Art. 56 states that "[W]here, in a court session, a judge believes that there may
} 
55-58, the procedure for excluding the evidence involves five steps: the first is to initiate the procedure in court examination; the second is courts' preliminary examination; the third is the prosecution's testifying in court; the fourth is cross-examination of both the accused and the prosecution; the fifth is courts' decision-making on the evidence.

Prosecutors also have the burden to prove whether torture has been used when a confession or other statement was obtained, apart from the police and courts.

\subsection{Exclusion of Illegally Obtained Evidence-Cases of Undue Coercion}

\subsubsection{Right to Remain Silent/Privilege Against Self-incrimination and Undue Coercion}

In PRC's criminal justice system, there is the "red line" drawn when fact-finding is deemed invasive with regard to individual rights, and not clear definition of undue coercion. In fact, the accused have no legal right to remain silent during interviews or interrogations in the criminal process, and only have the legal privilege against self-incrimination at a very basic level, as implied in Art. 50 of the 2012 CPL.

\subsubsection{Exclusionary Rules for Illegally Gathered Evidence in Cases of Undue Coercion (Other Than Torture)}

\subsubsection{Legal Framework}

There are some statutory rules governing the exclusion process of evidence in the case of (possible) undue coercion. Justifications for the exclusionary rules according to the law on the books are diverse. They are mainly safeguarding the respect for human rights and justice.

be any illegal obtainment of evidence as described in Art. 54 of this Law, the judge shall conduct an investigation in court regarding the legality of obtainment of evidence. A party or the defender or litigation representative thereof shall have the right to apply to a people's court for excluding illegally obtained evidence. Relevant clues or materials shall be provided for an application for excluding illegally obtained evidence." Art. 57 states that "[D]uring the investigation in court regarding the legality of obtainment of evidence, a People's Procuratorate shall prove the legality of obtainment of evidence. If the existing evidentiary materials cannot prove the legality of obtainment of evidence, the People's Procuratorate may request the people's court to notify relevant investigators or other persons to appear before court to explain; and the people's court may notify relevant investigators or other persons to appear before court to explain. The relevant investigators or other persons may also file a request for appearing before court to explain. The relevant persons notified by the people's court shall appear before court." Art. 58 states that "[W] here, at trial, any illegal obtainment of evidence as described in Art. 54 of this Law is confirmed or cannot be ruled out, the relevant evidence shall be excluded.". 
The exclusion of witness testimony collected by illegal means is mandatory in the cases of undue coercion and the exclusion of material or documentary evidence collected by such means is discretionary, as showed in Art. 40 of the 2012 CPL. By the law, there are also some exceptions to the above principle of mandatory exclusion.

\subsubsection{Practice; (High Court) Jurisprudence}

In practice, courts hardly recognize the general "exclusionary rule" in cases of undue coercion in order to control crime. But they often read the duty to find the truth into specific rules, so as to overrule explicit or implied exclusionary rules against law.

\subsubsection{Institutional Arrangements Securing the Right to Remain Silent}

There is no institutional arrangement safeguarding the right to silence. Given the common goal of crime control, the authorities have no interest in limiting fact-finding.

\subsubsection{Admissibility of Indirect Evidence ("Fruits of Poisonous Tree") in Cases of Undue Coercion}

\subsubsection{Legal Framework}

China's criminal justice system does address the problem of indirect evidence gained through evidence obtained by undue coercion, but not acknowledge a "fruit of the poisonous tree" doctrine in any statutory rules. Hence, there is no legal framework on admissibility of indirect evidence in cases of undue correction.

\subsubsection{Practice; (High Court) Jurisprudence}

Also, there is no clear justification for the exclusion of indirect evidence in China's law or practice. So far, no court practices such exclusion in any cases of undue correction.

\subsubsection{Remedies Following Violations of Exclusionary Rules}

There are remedy procedures with regard to a possible use of undue coercion, as showed in Arts. 55 to 57 of the 2012 CPL in China, but no such procedures to remedy the right to silence. In China's criminal justice system, these articles also 
provide for a standard procedure for testing statements for the use of undue coercion according to the law. In law, the law enforcement authorities have the burden to prove whether or not undue coercion has been used when a confession or other statement was obtained. In practice, the actual situation on the burden of proof is quite diverse.

\section{Statistics}

There are limited statistics on the implementation of exclusionary rules available in Mainland China. They include official data on new progress in implementation of exclusionary rules and academic findings on problems in the actual implementation.

On the one hand, academic research based on data cannot show significant progress after evidence reforms. For instance, the Criminal Procedure Law Institution of China University of Political Science and Law developed a pilot project on exclusionary rules in 2009 at three Basic Peoples' Courts (BPCs) out of nine BPC sin Yancheng City of Jiangsu Province. The three ones received 34 cases involving the application for illegally obtained evidence for a period of six months, from May 28 to November 28, 2010. The rate of applications was 5.2\% in the three, higher than $0.6 \%$ as the rate in other six BPCs located in the same City during the same period of time. Also, the rate of cases with lawyers involved was $47.8 \%$ in the three pilots during the above period, higher than $33.9 \%$ as the rate in other six BPCs during the same period, and $30.7 \%$ as the rate in the three pilots during six months before the pilot period. ${ }^{89}$ With more lawyers to help apply for excluding the evidence, defendants' expectation from lawyers was increasing, but their initiative application was reported to be rare. ${ }^{90}$

Another example is an academic survey on the actual implementation of the 2010 Evidence Regulations among judges responsible for criminal trials in a court located in Guangzhou City of Guangdong Province. ${ }^{91}$ In about $25 \%$ of cases that interviewed judges here, the defence argued that pre-trial confessions were illegally obtained before the implementation, whereas after that the defence did so in about $30 \%$ of the cases. Although the defence can provide clues or evidence sources in $55 \%$ of the $30 \%$ part, courts only identify $5 \%$ of the $55 \%$ as cases involving illegally obtained evidence.

Also, the cases involving torture was found to be about $10 \%$ of all cases in the survey and only $1 \%$ of those involving torture had been officially identified as those with tortured confession. About $10 \%$ of the cases were found to include technical flaws, of which $85 \%$ can be used as the basis of deciding cases after "corrections or reasonable explanations". Although about $5 \%$ of interrogation transcripts were not

\footnotetext{
${ }^{89}$ GUO Xinyang, 2012.

${ }^{90} \mathrm{Ibid}$.

${ }^{91}$ HE Jiahong, 2013.
} 
checked, confirmed, signed or fingerprinted by suspects, almost all or exactly about $90 \%$ of the flawed were still used for deciding cases. In the surveyed cases, about $50 \%$ of material or documentary evidence was from suspects' confession or identification. Among the half, about 5\% of it involves tortured confession and another $10 \%$ or so involves threats, enticement and deceit. Even so, about $80 \%$ of the flawed half was still used as the basis of deciding cases. Among the material or documentary evidence that the police provided to the court, approximately $15 \%$ involves technical flaws, of which about $80 \%$ have been "corrected or reasonably explained" for being used as the bases of deciding cases. Before the implementation, in cases involving requests of proving the course of collecting evidence to be legal, about $85 \%$ of all cases involve the approach of official seals in explanatory materials, whereas $80 \%$ of the cases after the implementation. ${ }^{92}$ There is no significant change on the new reforms in practice.

Another empirical study of the early implementation of the new $C P L$ also showed problems in implementation. ${ }^{93}$ A survey of recording practices by prosecutors in Fujian Province from January to October 2013 has shown some prosecutors or leaders cannot fully recognise the important role of synchronised recording in preventing torture and excluding tortured confession. ${ }^{94}$ Also, local people's Procuratorates' investment in recording technology was far from insufficient to meet the actual needs of providing dedicated interrogation rooms and other recording equipments. ${ }^{95}$ This survey found that among the 96 Procuratorial agencies in the same province, two thirds $(67 \%)$ only had one employee to record interrogations, and $61 \%$ of such agencies merely have part-time employees to do so. The serious lack of recording employees reveals the fact that interrogators often or at least sometimes conduct recordings. Clearly, this practice fails to separate sections in conducting recording from those in interrogating suspects during investigation, detrimental to justice. ${ }^{96}$

In fact, prosecutors showed no interest in recording requirements or concern about allegations of torture in interrogations before or after the implementation of the 2012 $C P L$. Another survey was conducted among 642 participants as prosecutors, judges, police officers or lawyers of a Chinese province, in order to examine their attitudes towards torture during investigation. ${ }^{97}$ The finding is that $79.7 \%$ of lawyers reported that prosecutors had no response to the allegation of torture in interrogations, and that $45.7 \%$ of the prosecutors agreed that they would not address the allegation. ${ }^{98}$

\footnotetext{
${ }^{92}$ Art. 7(3) of Exclusionary Rules states that explanation documents provided by prosecutors with stamps on, cannot be admitted as evidence to prove the legitimacy of collecting evidence, unless the relevant investigators signed their names on or annexed their seals to the documents.

${ }^{93}$ LI Mingrong//TENG Zhong/Zhang Min, 2014 at 40.

${ }^{94}$ Ibid.

${ }^{95} \mathrm{Ibid}$.

${ }^{96}$ Ibid. at 41.

${ }^{97}$ LIANG Bin/HE Ni Phil/LU Hong, 2014 at 591.

${ }^{98} \mathrm{Ibid}$. at 594.
} 


\section{Conclusion}

In Chinese law on the books, the interest in finding the truth should be balanced with suspects' or the accused's rights. Particularly since the adoption of the 2012 $C P L$ effective from 2013, more and more evidence illegally obtained has been successfully excluded from use at trial. In a sharp contrast with numerous rejections in such cases, successful exclusion is very rare in practice. These facts have suggested that reforms to PRC's criminal justice system are intended to promote, but actually fail to ensure, respect for relevant human rights in the criminal process due to institutional obstacles. The above imbalance between the interest and rights has persisted for many decades.

The implementation of excluding tortured confession in China has not been used to promote human rights, ensure justice or increase the reliability of evidence collected by interrogation. Given a combination of selective exclusion or recording at the discretion and institutional hurdles to challenging admissibility of a confession as evidence, recordings are often abused as a tool for hiding torture or coercion in interrogations. The actual operation of the exclusionary rules in China is not satisfying without better protection of the accused from torture or coercion within the current institutional environment.

Hence, China's institutions of criminal justice must change and become more truly adversarial for exclusion of evidence to better prevent torture. In order to better find the truth and properly enforcing People's Courts, prosecutors and the police must pay better attention to due process, human rights and material evidence. By empowering defence lawyers to seek the exclusion of improperly-obtained evidence, China could better protect human rights and enhance the ability of courts to find the truth.

\section{References}

\section{Books}

Nolan, James L., Legal Accents, Legal Borrowing: The International Problem-Solving Court Movement, Princeton 2009. [Nolan, 2009]

郎胜 (LANG Sheng (ed.)): 中华人民共和国刑事诉讼法释义 (最新修订版) (Explanations of Criminal Procedure Law in the People's Republic of China) new edition, Beijing 2012. [LANG Sheng (ed.), 2012]

张军 (ZHANG Jun): 刑事错案追究 (Research on Criminal Wrongful Conviction), Beijing 1990. [ZHANG Jun, 1990] 


\section{Journal Articles}

Daum, Jeremy, 'Tortuous Progress: Early Cases Under China's New Procedures for Excluding Evidence in Criminal Cases', (2011) 43 New York University's Journal of International Law and Politics, 699-711. [Daum, 2011]

LIANG Bin/HE Ni Phil/LU Hong, 'The Deep Divide in China's Criminal Justice System: Contrasting Perceptions of Lawyers and the Iron Triangle', (2014) 62 Crime, Law and Social Change, 585-601. [LIANG Bin/HE Ni Phil/LU Hong, 2014]

Roach, Kent, 'Exonerating the Wrongfully Convicted: Do We Need Innocence Hearings', in: Margaret E. Beare (eds.), Honouring Social Justice: Honouring Dianne Martin, Toronto 2009, 55-84. [Roach, 2009]

Sherrin, Christopher, 'Declarations of Innocence', (2010) 35 Queen's Law Journal, 437-492. [Sherrin, 2010]

Time, Victoria M., 'Evidence Gathering: The Exclusionary Rule in China', (2012) 1 International Law Research, 144-148. [Time, 2012]

YU Ping, 'Glittery Promise vs. Dismal Reality: The Role of a Criminal Lawyer in the People's Republic of China after the 1996 Revision of the Criminal Procedure Law', (2002) 35 Vanderbilt Journal of Transnational Law, 827-864. [YU Ping, 2002]

陈如超 (CHEN Ruchao): 刑讯逼供的中国治理 (The Chinese Rectification of Inquisition by Torture), 甘肃政法学院学报 (Gansu Zhengzhi Хиеуuan Xuebao) 2015-1, 1-17. [CHEN Ruchao, 2015]

陈瑞华 (CHEN Ruihua): 论被告人口供规则 (On the Rules about the Confession of the Accused), 法学杂志 (Faxue Zazhi) 2012-6, 46-55. [CHEN Ruihua, 2012]

陈瑞华 (CHEN Ruihua): 非法证据排余规则的适用对象 (The Exclusive Object of Illegal Evidence Exclusion Rule: An Analysis of Involuntary Confession), 当代法学 (Dangdai Faxиe) 2015-1, 37-48. [CHEN Ruihua, 2015]

董晓伟 (DONG Xiaowei): 十年刑讯逼供致人死亡案件的回顾与反思 (Retrospection and Rethink of the Cases With Death Consequence because of the Inquisition by Torture in the Last Ten Years), (公安学刊〉一浙江公安专科学校学报 (Gongan Xuekan) - Zhejiang Gongan Zhuanke Xuexiao Xuebao) 2004-1, 5-7. [DONG Xiaowei, 2004]

杜豫苏 (DU Yusu): 非法证据排除审理程序的困境与完善 (The Dilemma of the Trial Process about the Exclusionary Rule and its Improvement), 法律科学 (Falü Kexue) 2013-6, 184-189. [DU Yusu, 2013]

高洁 (GAO Jie): 非法证据排除规则适用的实证㸴究—从 “中国裁判文书网”的100份裁判 文书谈起 (An Empirical Study on the Exclusionary Rule of Illegally Obtained Evidences), 江 苏警官学院学报 (Jiangsu Jingguan Хиеуuan Xиеbao) 2016-1, 31-35. [GAO Jie, 2016]

郭欣阳 (GUO Xinyang): 检察改革视域中的非法证据排余规则 (The Exclusionary Rule in Light of Procuratorial Reform), 国家检察官学院学报 (Guojia Jianchaguan Xueyuan Xuebao) 2012-5, 9-16. [GUO Xinyang, 2012]

何家弘 (HE Jiahong): 刑事诉讼中证据调查的实证硎究 (Empirical Research on Evidence Investigation in Criminal Litigation), 中外法学 (Zhongwai Faxue) 2012-1, 173-189. [HE Jiahong, 2012]

何家弘 (HE Jiahong): 适用非法证据排除规则需要司法判例 (Judicial Precedents are Needed in the Application of Exclusionary Rule), 法学家 (Faxue Jia) 2013-2, 106-118. [HE Jiahong, 2013]

孔一 (KONG Yi): 刑讯逼供调查 (Survey of the Inquisition by Torture), 青少年犯罪㸴究 (Qingshaonian Fanzui Yanjiu) 2001-2, 11-15. [KONG Yi, 2001]

李明蓉、滕忠、张旻 (LI Mingrong/TENG Zhong/Zhang Min): 福建检察机关刑诉法实施情况 调研报告 (Research Report on the Procuratorates' Implementation of the Criminal Procedure Law in Fujian Province), 国家检察官学院学报 (Guojia Jianchaguan Xueyuan Xuebao) 2014-5, 40-54. [LI Mingrong/TENG Zhong/Zhang Min, 2014] 
林国强 (LIN Guoqiang): 论毒树之果在我国刑事诉讼法中的适用空间 (On the Application of the Fruits of Poisonous Tree in Chinese Criminal Procedure Law), 河北法学 (Hebei Faxue) 2013-10,182-187. [LIN Guoqiang, 2013]

林莉红、余涛、张超 (LIN Lihong/YU Tao/ZHANG Chao): 刑讯逼供社会认知状况调查报告 (监狱服刑人员卷) (Survey of the Cognition About the Inquisition by Torture (Part: Prisoner)), 法学评论 (Faxue Pinglun) 2009-3, 119-129. [LIN Lihong/YU Tao/ZHANG Chao, 2009]

林莉红、余涛、张超 (LIN Lihong/YU Tao/ZHANG Chao): 刑讯逼供社会认知状况调查报告 (下篇.警察卷) (Survey of the Cognition About the Inquisition by Torture (Part Two: Police)), 法学评论 (Faxue Pinglun) 2006-5, 123-140. [LIN Lihong/YU Tao/ZHANG Chao, 2006]

宁平 (NING Ping): 我国 “抗辩式” 侦查讯问模式构建的必要性及可行性探究 (Research on the Necessity and Feasibility of the Establishment of an Adversarial Investigative Interrogation Model in China), 犯罪硎究 (Fanzui Yanjiu) 2015-4. 39-46. [NING Ping, 2015]

田文昌 [TIAN Wenchang]: 刑事辩护不能放纵非法证据 (Criminal Defense Cannot Abide Illegal Evidence), 法制周末 (Fazhi Zhoumo), 11 January 2011, available online at <http:// opinion.hexun.com/2011-01-11/126731224.html>, accessed 31 October 2018. [TIAN Wenchang]

王超 (WANG Chao): 非法证据排余规则的虚置化隐忧与优化改革(The Hidden Worry of an Empty Shell in Regard of the Exclusionary Rule and the Optimum Reform of This Rule), 法学 杂志 (Faxue Zazhi) 2013-12, 100-108. [WANG Chao, 2013]

吴宏耀 (WU Hongyao): 非法证据排除的规则与实效一一兼论我国非法证据排除规则的完善 进路 (The Exclusionary Rule, its Actual Effect and the Approach of Improvement on the Exclusionary Rule in People's Republic of China), 现代法学 (Xiandai Faxue) 2014-4, 121 130. [WU Hongyao, 2014]

谢澍 (XIE Peng): 刑事审判公开的信息化转型 (The Transformation of Informatisation in the Criminal Public Trial), 中国刑事法杂志 (Zhongguo Xingshifa Zazhi) 2012-12, 65-75. [XIE Peng, 2012]

间召华 (YAN Zhaohua): “名禁实允”与 “虽令不行”: 非法证据排除难硎究 (Forbid Nominally, but Allow Actually and Despite Decree, but not Execute: Research on the Difficulties of the Exclusionary Rule), 法制与社会发展 (Fazhi Yu Shehuifazhan) 2014-2, 181-192. [YAN Zhaohua, 2014]

杨明、张海林 [YANG Ming/ZHANG Hailin]: 非法证据排除规则施行 4 月律师称新规作用有 限 (Evidence Exclusion off to a Shaky Start), 瞭望东方周刊(Liaowang Dongfang Zhoukan), 29 November 2010, available online at <http://news.sohu.com/20101129/n277987689.shtml>, accessed 31 October 2018. [YANG/ZHANG, 2010]

杨宇冠 (YANG Yuguan): 论法治视野下的非法证据排除规则 (On the rule of excluding illegal evidence under the rule of law), 证据科学 (Zhengju Kexиe) 2015-4, 389-399. [YANG Yuguan, 2015]

周长军 (ZHOU Changjun): 微博直播庭审对侦查法治化的可能意义 (The Possible Importance of the Trial Live Broadcasting by Weibo-Software to the Rule by Law during the Investigation), 法学论坛 (Faxue Luntan) 2014-1. 90-99. [ZHOU Changjun, 2014]

左卫民 (ZUO Weimin): “热”与 “冷” 非法证据排除规则适用的实证砶究 (The Favourite and the Underdog in the Empirical Research on the Exclusionary Rule), 法商㸴究 (Fashang Yanjiu) 2015-3,151-160. [ZUO Weimin, 2015a]

左卫民 (ZUO Weimin): 中国 《刑事诉讼法》第三次修改前瞻 (Prospect of the Third Reform of the Chinese Criminal Procedure Code), 现代法学 (Xiandai Faxue) 2015-4. 3-11. [ZUO Weimin, 2015b]

\section{Internet Links for UN-Documents}

United Nations Committee Against Torture, 'Second Periodic Reports of States Parties Due in 1993: China. (15 February 1996)’ CAT/C/20/Add.5 (1996), available online at <http:// 
tbinternet.ohchr.org/_layouts/treatybodyexternal/Download.aspx?symbolno=CAT\%2fC\%

2f20\%2fAdd.5\&Lang=zh>, accessed 31 October 2018. [CAT Report, 1996a]

\title{
Case List
}

\author{
Case FAN Qihang \\ Case NIAN Bin \\ Case SHE Xianglin \\ Case ZHAO Zuohai \\ Case ZHANG Guoxi
}

Professor Na Jiang holds a Ph.D. from Durham University (UK) where she successfully completed her thesis titled "China and international human rights: Capital punishment and detention for re-education in the context of the International Covenant on Civil and Political Rights." Professor Jiang's research interests include comparative law, international human rights law, criminal law and procedure, and exclusionary rules in the Chinese criminal justice system. She joined Beijing Normal University in 2008 where she has been a professor of law since 2015 . She has published numerous articles and books in English and Chinese in the areas of criminal law, criminal procedure, and international human rights law in the Western world and China.

Open Access This chapter is licensed under the terms of the Creative Commons Attribution 4.0 International License (http://creativecommons.org/licenses/by/4.0/), which permits use, sharing, adaptation, distribution and reproduction in any medium or format, as long as you give appropriate credit to the original author(s) and the source, provide a link to the Creative Commons license and indicate if changes were made.

The images or other third party material in this chapter are included in the chapter's Creative Commons license, unless indicated otherwise in a credit line to the material. If material is not included in the chapter's Creative Commons license and your intended use is not permitted by statutory regulation or exceeds the permitted use, you will need to obtain permission directly from the copyright holder.

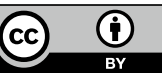

